\title{
The relationship between teacher candidates' self-efficacy levels and lifelong learning tendencies
}

\author{
Serap Tüfekçi Aslım ${ }^{* a}$, Handan Kocabatmaz ${ }^{* * a}$ \\ ${ }^{a}$ Gazi University, Gazi Faculty of Education, Ankara/Turkey
}

\begin{tabular}{ll}
\multicolumn{2}{l}{ Article Info } \\
\hline DOI: $10.31704 /$ ijocis.2019.008 \\
\hline \multicolumn{2}{l}{ Article History: } \\
Received $\quad 9$ April 2019 \\
Revised & 9 May 2019 \\
Accepted & 23 May 2019 \\
Online & 30 June 2019 \\
\hline
\end{tabular}

Keywords:

Self-efficacy,

Lifelong learning,

Pre-service teacher.

Article Type:

Research paper

\begin{abstract}
This study aims to reveal whether there is a meaningful difference between preservice teachers' self-efficacy levels and their tendencies towards lifelong learning and the relationship between them according to gender and grade. The sample of the study based on correlational survey model consisted of 242 preservice primary school teachers at Gazi Faculty of Education in Gazi University. "Self-efficacy Scale" and "Lifelong Learning Tendency Scale" were used for data collection. While preservice primary school teachers' self-efficacy levels were found above the average in general, there was no meaningful difference according to gender and grade. Preservice teachers' tendencies towards lifelong learning were found high, but did not change according to gender. Freshmen preservice teachers' tendencies were found higher. There is a medium-level (.53), positively meaningful relationship between preservice teachers' self-efficacies and their tendencies towards lifelong learning. Results of the analyses also reveal that $28.00 \%$ of the total variance regarding tendencies towards lifelong learning is explained with self-efficacy beliefs.
\end{abstract}

\section{Öğretmen adaylarının öz yeterlik düzeyleri ile yaşam boyu öğrenme eğilimi arasındaki ilişkinin incelenmesi}

\begin{tabular}{|c|c|}
\hline Makale Bil & \\
\hline DOI: 10.31 & 04/ijocis.2019.008 \\
\hline Makale Ge & mişi: \\
\hline Geliş & 9 Nisan 2019 \\
\hline Düzeltme & 9 Mayıs 2019 \\
\hline Kabul & 23 Mayıs 2019 \\
\hline Çevrimiçi & 30 Haziran 2019 \\
\hline $\begin{array}{l}\text { Anahtar Ke } \\
\text { Öz yeterlik } \\
\text { Yaşam boy } \\
\text { Öğretmen }\end{array}$ & $\begin{array}{l}\text { meler: } \\
\text { öğrenme, } \\
\text { dayı. }\end{array}$ \\
\hline $\begin{array}{l}\text { Makale Tü } \\
\text { Özgün Mal }\end{array}$ & \\
\hline
\end{tabular}

\section{Öz}

Araştırma öğretmen adaylarının öz yeterlik düzeyi ile yaşam boyu öğrenme eğilimlerinin; cinsiyet ve sınıf düzeyine göre anlamlı bir şekilde farklılaşıp farklılaşmadığını ve anlamlı bir ilişkinin olup olmadığını belirlemek amacı ile yapılmıştır. İlişkisel tarama modeline dayalı olan araştırmanın örneklemini Gazi Üniversitesi Gazi Eğitim Fakültesi'nde öğrenim gören 242 sınıf öğretmeni adayı oluşturmaktadır. Çalışmada "öz yeterlik ölçeği" ve "yaşam boyu öğrenme eğilimleri ölçeği" veri toplama aracı olarak kullanılmıştır. Öğretmen adaylarının öz yeterlik düzeyi genel olarak ortalamanın üstünde bulunurken cinsiyete ve sınıf düzeyine göre anlamlı biçimde farklılaşmadığı saptanmıştır. Öğretmen adaylarının yaşam boyu öğrenme eğilimleri yüksek bulunmakla birlikte cinsiyete göre değişmemektedir ancak birinci sınıf öğretmen adaylarının eğilimi daha yüksek bulunmuştur. Öğretmen adaylarının öz yeterlik ve yaşam boyu öğrenme eğilimleri arasında orta (.53) düzeyde, pozitif yönlü anlamlı bir ilişki vardır. Analiz sonuçları yaşam boyu öğrenme eğilimine ilişkin toplam varyansın, \%28.00'inin öz yeterlik inancı ile açıklandığını göstermektedir.
* Author: tserap@gazi.edu.tr
** Author: handank@gazi.edu.tr

Orcid ID: https://orcid.org/0000-0002-6150-9391

Orcid ID: https://orcid.org/0000-0002-1446-9761 


\section{Introduction}

The fact that information, which changes and grows rapidly, and influences social lives along with qualifications expected from individuals spontaneously. During this process, as individuals' knowledge, attitudes, aims and expectations change is naturally the design of the formal education needs to be structured so as to meet the individuals' needs. Passing on and developing culture in a society, enabling individuals to be social, furnishing them with the required knowledge and skills can and will only be possible if and when schools and teachers are able to adapt to the changes and developments. This is a sine qua non since inputs of education and teaching system, namely education and teaching programs, teaching materials, technological infrastructure, and physical environment is shaped by the teachers' self-efficacy levels. Teachers' self-efficacy is formed by their perceptions about their professional knowledge and skills such as general knowledge, professional teaching knowledge and field knowledge as well as their ability to carry out duties and responsibilities (Ay, 2007; Şahin, 2010).In Social-cognitive Theory, Bandura defines the concept of self-efficacy as an individual's self-belief and self-confidence in his ability to start a certain task and continue until he reaches a result (Bandura, 1994; Bandura, 1997; Golightly, 2007). According to Bandura (1994), self-efficacy is individuals' own perceptions and self-judgements regarding managing their own lives, solving problems, their ability to perform cognitive, psychomotor, social behaviors required to carry out a task. Individuals with high perceptions of their self-efficacy levels rely on their skills and outputs, endeavor to improve them, and they can change negative outcomes (Carver \& Scheier, 2003; Pajares, 2002).

In the field of education, teacher self-efficacy belief is synonym with the teacher's performance and their success in effectiveness of teaching. However, self-efficacy belief is a pushing force which shapes and increases teacher's performance level rather than a feature which eliminates teacher's incompetencies in the field and profession (Goddard, Hoy \& Woolfolk-Hoy, 2000; Tschannen-Moran \& Woolfolk-Hoy, 2001). Self-efficacy does not refer to the characteristics of a person, but it is the state of an individual's perception of and belief in himself in regards to his characteristics (Akkoyunlu, Leithwood, 2007; Orhan \& Umay, 2005).

A number of studies reveal that teachers with high levels of efficacy are innovative, skillful in classroom management, effective in communication. They prefer student-centered, needs-oriented, more planned and organized instructional design in line with high professional standards; teachers with high levels of efficacy encourage students. They mainly employ humanistic approach and make use of various methods and techniques (Balcı, 2001; Özenoğlu-Kiremit, 2006; Woolfolk \& Hoy, 1990). The teachers' high self-efficacy perceptions enhance their motivation and efforts, and affects their performance (Bıkmaz, 2004; Goddard et. al., 2000), and contributes positively to student's learning and success (Goddard, 2001, 2004; TschannenMoran \& Hoy, 2001). Furthermore, Schmitz (2000) maintains that high self-efficacy enables teachers to cope with negative factors and stress faced in the profession, and that teachers with high self-efficacy can deal with problems and barriers more easily and they can carry on teaching by taking necessary decisions fast (Cited by Yılmaz et. al., 2004).

Individuals who are self-confident, aware of their needs and skills, and have high expectations, in other words have high self-efficacy endeavor, show proficiency and high performance, which enhances their tendencies towards lifelong learning (Schunk, 1996). Lifelong learning means an individual being eager, aware, and in need of continuous learning; making learning a part of life by adopting attitudes and habits.

Lifelong learning includes all sorts of learning facilities in which individuals participate to develop and increase their quality of their knowledge, skills, awareness and proficiency (Akkoyunlu, 2008; Ersoy \& Yllmaz, 2005; HBÖ, 2009; Turan 2005). These learning facilities take place in people's lives (Diker-Coşkun \& Demirel, 2012). On the other hand, Shuman et al. (2005) define skills regarding lifelong learning as being competent in information technologies and high-level thinking, reaching and using the necessary true knowledge, having selfcontrol, adapting to innovations and changes, being eager to learn, making and following plans and strategies for learning.

A lifelong learner is able to plan and evaluate his own learning; as an active student, he can continue his life by integrating the knowledge gained from various subjects both at school and outside the school (Knapper \& Cropley, 2000). An individual with a tendency towards lifelong learning is motivated, enduring, curious, able to organize his learning (Diker-Coşkun \& Demirel, 2012), and interested in scientific innovations, social developments and changing practices (Akkoyunlu, 2008). Besides, there are explanations which describe lifelong learning as an economical practice, a plan of the aging population to adapt to new working and living 
conditions, and a movement of globalization. For example, for Aspin and Chapman (2001) the aim of lifelong learning is to make the society more productive and fasten economic growth by enabling individual development. In Turkey, aims of lifelong learning are emphasized in similar terms in line with the eighth fiveyear development plan; to enable individuals' personal development, to put into practice social integration and economic growth (DPT, 2001, p. 10).

Education systems and teachers play a key role in gaining lifelong learning skills at an early age (Akkoyunlu, 2008). Selvi (2011) states those teachers' proficiencies in lifelong learning need to be dealt with by teachers by being lifelong learners, and by being responsible for developing their students' lifelong learning skills. As part of their profession teachers, along with the new generation, need to follow the innovations regarding needs, be aware of social developments, improve their skills continuously, and have the skills for lifelong learning. Teachers' providing students with motivation, awareness, attitudes and habits regarding learning, in other words, teachers' raising awareness of lifelong learning and making individuals able to adapt to developments even after the formal education and develop their skills is significant in maintaining individual and social growth.

In this regard, identifying preservice teachers' self-efficacy beliefs and their tendencies towards lifelong learning before they start this profession, and eliminating their incompetencies -if there are any- will contribute to raising individuals who are lifelong learners and have high self-efficacy, which could also provide social benefit.

\section{Aim of the Study}

The aim of this study is to identify whether preservice primary school teachers' self-efficacy levels and their tendencies towards lifelong learning differ according to gender and grade, and whether there is a meaningful relationship between preservice primary school teachers' self-efficacy levels and their tendencies towards lifelong learning. In line with this aim, answers were sought for the following questions:

1. What are preservice teachers' self-efficacy levels?

2. Do preservice teachers' self-efficacy levels differ according to their gender?

3. Do preservice teachers' self-efficacy levels differ according to their grade?

4. What are the levels of preservice teachers' tendencies towards lifelong learning?

5. Do preservice teachers' tendencies towards lifelong learning differ according to their gender?

6. Do preservice teachers' tendencies towards lifelong learning differ according to their grade?

7. Is there a meaningful relationship between preservice teachers' self-efficacy levels and their tendencies towards lifelong learning?

8. Do preservice teachers' self-efficacy levels predict their tendencies towards lifelong learning?

\section{Method}

\section{Model of the Study}

This study is based on correlational survey model, which is one of the survey models. Survey models aim to describe a past or current situation as it was/is (Karasar, 2013).

\section{Sample}

The sample consisted of 242 undergraduate primary school teachers studying at Gazi Faculty of Education in Gazi University. Convenience sampling method was used in order to determine the participants. In convenience sampling (convenient sampling) the study is carried out with participants who are available to the researcher, suitable and volunteer for the research, and easy to reach (Gravetter \& Forzano, 2012). Out of 242 participants, 202 are female and 40 are male preservice teachers. Out of these participant preservice teachers, 70 are freshmen, 67 are sophomores, 62 are juniors, and 43 are seniors. 


\section{Data Collection Tool}

Two different tools were used for data collection in this study: "Self-efficacy Scale" and "Lifelong Learning Tendency Scale". "Self-efficacy Scale" was developed by Sherer et al. (1982), and it was adapted into Turkish by Yıldırım and İlhan (2010). The scale, which included options varying from "none" to "very well" for the question "How well does it describe you?", was structured in five-point Likert type. As a result of the confirmatory factor analysis, the scale was identified as three-factor, which consists of three dimensions: "starting", "not giving up" and "effort to continue-persistence" respectively. The scale includes 17 items and Cronbach's Alpha reliability co-efficient was found as $\alpha=.80^{\prime}$ by Yıldırım and illhan (2010). Cronbach's Alpha reliability co-efficient of the scale was calculated as $\alpha=.85$ in this study. "Lifelong Learning Tendency Scale" was developed by Coşkun-Diker (2009). The scale was structured in six-point Likert type varying as such: "strongly agree", "partly agree", "slightly agree", "slightly disagree", "partly disagree", "totally disagree". The 27-item scale, which deals with characteristics of lifelong learners in positive and negative aspects, consists of four sub-dimensions namely "motivation", "persistence", "lack of self-regulation", and "lack of curiosity". Cronbach's Alpha reliability coefficient of the scale is $\alpha=.89$ (Coşkun-Diker, 2009). Cronbach's Alpha reliability co-efficient of "Lifelong Learning Tendency Scale" was found as $\alpha=0.91$ in this study.

\section{Analysis of the Data}

Preservice primary school teachers' self-efficacy and their tendencies towards lifelong learning were described according to their gender and grade, whether self-efficacy beliefs and tendencies towards lifelong learning differ according to their gender and grade was examined via the collected data. Statistically, total average scores and standard deviations were calculated to describe preservice teachers' self-efficacy and tendencies towards lifelong learning. Besides, minimum, medium and maximum scores to be obtained through the application of each scale were taken as criteria. Median scores for each scale were calculated based on the premise that results show a normal distribution.

Options in the 17-item Self-efficacy scale are in 5-point Likert type, varying between 1 "none" and 5 "very well". 3 was accepted as the "medium" point. Regarding the scores to be obtained on the scale, minimum score was determined as 17 ; median as 51 ; and maximum score as 85 . Distribution of scores regarding subdimensions of the Self-Efficacy Scale is as follows:

- Scores to be obtained from "Starting" dimension, which includes 9 items, are: minimum 9; median 27; maximum 45.

- Scores to be obtained from "Not giving up" dimension, which includes 5 items, are: minimum 5; median 15; maximum 25.

- Scores to be obtained from "Continuation" dimension, which includes 3 items, are: minimum 3; median 9; maximum 15.

Options in the 27-item "Lifelong Learning Tendency" scale are in 6-point Likert type, varying between 1 and 6. 3,5 was accepted as the "medium" point between the options "slightly agree" and "slightly disagree". Regarding the scores to be obtained on the scale, minimum score was determined as 27; median as 94,5; and maximum score as 162.Distribution of scores regarding four sub-dimensions of the Lifelong Learning Tendency scale is as follows:

- Scores to be obtained from "Motivation" dimension, which includes 6 items, are: minimum 9; median 21; maximum 36.

- Scores to be obtained from "Persistence" dimension, which includes 6 items, are: minimum 6; median 21; maximum 36.

- Scores to be obtained from "Organizing Learning" dimension, which includes 6 items, are: minimum 6; median 21; maximum 36.

- Scores to be obtained from "Lack of Curiosity" dimension, which includes 9 items, are: minimum 9; median 31.5; maximum 54. 
The obtained data were explained through the interpretation that when a participant's "attitude score" falls within the median of the dimension of the scale, this participant's attitude is either at medium rate or not formed (Turgut \& Baykul, 1992). In the study, before the analyses regarding variables were carried out, Kolmogorov-Smirnov Test (Büyüköztürk, 2007) was applied to check if the set of data met parametric test requirements. When the $p$ value in Kolmogorov-Smirnov test is larger than $p>.05$, it can be stated that the distribution does not show meaningful difference from normal distribution, that is to say, it complies with the normal distribution (Büyüköztürk, 2007). As a result of the controls it was found that the distribution met parametric test requirements. T test was used in making comparisons between self-efficacy and tendency towards lifelong learning according to gender while one-way analysis of variance (ANOVA) was used to make comparisons between self-efficacy and tendency towards lifelong learning according to grade. Upon the appearance of meaningful difference in one-way analysis of variance (ANOVA), the source of difference was examined through Scheffe test. Pearson Moment two-way correlation analysis ( $r$ ) was used to determine whether there was a linear relationship between preservice teachers' self-efficacy levels and their tendencies towards lifelong learning; simple regression analysis was used to determine the potential of predictor variable (self-efficacy level) to estimate the dependant variable (tendency towards lifelong learning).

\section{Findings}

The findings of the study are presented using sub-problems of the research. Table 1 shows preservice teachers' self-efficacy mean score distributions in total and in sub-dimensions "starting", "not giving up", "continuation". Total mean score of preservice teachers' self-efficacy is 62.70. Mean score of preservice teachers' self-efficacy is over scale median (51). Preservice teachers' self-efficacy mean scores in subdimensions "starting", "not giving up" and "continuation" are slightly over scale median. Thus, it could be stated that preservice teachers' self-efficacy levels are high. Table 2 shows whether preservice teachers' selfefficacy levels differ according to gender:

Table 1.

Preservice Teachers' Self-Efficacy Levels

\begin{tabular}{lrrr}
\hline Dimension & $\mathbf{N}$ & $\overline{\boldsymbol{X}}$ & $\mathbf{S}$ \\
\hline Starting & 242 & 33.60 & 5.83 \\
Not giving up & 242 & 18.44 & 3.53 \\
Continuation & 242 & 10.62 & 1.92 \\
Total self-efficacy & 242 & 62.70 & 9.40 \\
\hline
\end{tabular}

Table 2.

Distribution of Preservice Teachers' Self-Efficacy Levels according to Gender

\begin{tabular}{llrrrrrr}
\hline Dimension & Gender & $\mathbf{N}$ & $\overline{\boldsymbol{X}}$ & $\mathbf{S}$ & $\mathbf{d f}$ & $\mathbf{t}$ & $\mathbf{P}$ \\
\hline Starting & Female & 202 & 33.62 & 5.88 & 238 & .00 & .97 \\
& Male & 40 & 33.61 & 5.67 & & & \\
Not giving & Female & 202 & 18.35 & 3.56 & 238 & .87 & .68 \\
up Continuation & Male & 40 & 18.89 & 3.38 & & & \\
& Female & 202 & 10.54 & 1.96 & 238 & 1.43 & .09 \\
Total self- & Male & 40 & 11.02 & 1.68 & & & .61 \\
efficacy & Male & 202 & 62.53 & 9.61 & 238 & .55 \\
\hline
\end{tabular}

As Table 2 reveals, male preservice teachers' mean scores in "not giving up", "continuation" and "total" self-efficacy levels are higher than those of female preservice teachers. However, considering both the whole scale and its sub-dimensions, it is obvious that preservice teachers' self-efficacy levels do not differ meaningfully according to gender. In other words, both female and male preservice teachers have similar perceptions of their self-efficacies. 
Table 3.

Distribution of Preservice Teachers' Self-Efficacy Levels according to Grade

\begin{tabular}{|c|c|c|c|c|c|c|c|c|c|c|}
\hline Dimension & Grade & $\mathbf{N}$ & $\bar{x}$ & $\mathbf{S}$ & Source of variance & KT & KO & df & $\mathbf{F}$ & $\mathbf{p}$ \\
\hline \multirow[t]{5}{*}{ Starting } & 1. & 70 & 35.03 & 5.88 & Between Groups & 347.62 & 115.87 & 3 & 3.50 & .01 \\
\hline & 2. & 67 & 32.40 & 5.67 & Within Groups & 7863.67 & 33.041 & 238 & & \\
\hline & 3. & 62 & 32.62 & 5.86 & Total & 8211.29 & & 241 & & \\
\hline & 4. & 43 & 34.66 & 5.45 & & & & & & \\
\hline & Total & 242 & 33.62 & 5.83 & & & & & & \\
\hline \multirow[t]{5}{*}{ Not giving up } & 1. & 70 & 19.23 & 3.54 & Between Groups & 64.38 & 21.46 & 3 & 1.73 & .16 \\
\hline & 2. & 67 & 18.15 & 3.07 & Within Groups & 2943.40 & 12.36 & 238 & & \\
\hline & 3. & 62 & 17.95 & 3.63 & Total & 3007.79 & & 241 & & \\
\hline & 4. & 43 & 18.32 & 3.93 & & & & & & \\
\hline & Total & 242 & 18.44 & 3.53 & & & & & & \\
\hline \multirow[t]{5}{*}{ Continuation } & 1. & 70 & 10.49 & 2.31 & Between Groups & 3.53 & 1.17 & 3 & .31 & .81 \\
\hline & 2. & 67 & 10.56 & 1.69 & Within Groups & 890494 & 3.74 & 238 & & \\
\hline & 3. & 62 & 10.79 & 1.89 & Total & 894.02 & & 241 & & \\
\hline & 4. & 43 & 10.69 & 1.64 & & & & & & \\
\hline & Total & 242 & 10.62 & 1.92 & & & & & & \\
\hline Total Self- & 1. & 70 & 64.76 & 10.25 & Between Groups & 612.58 & 204.19 & 3 & 2.34 & .07 \\
\hline \multirow[t]{4}{*}{ efficacy } & 2. & 67 & 61.12 & 8.40 & Within Groups & 20716.1 & 87.04 & 238 & & \\
\hline & 3. & 62 & 61.38 & 9.30 & Total & 7 & & 241 & & \\
\hline & 4. & 43 & 63.69 & 9.14 & & 21328.7 & & & & \\
\hline & Total & 242 & 62.70 & 9.40 & & 6 & & & & \\
\hline
\end{tabular}

According to Table 3. considering mean scores in "starting", "not giving up" and "total", it is seen that the highest mean score belongs to freshmen preservice teachers with a slight difference, and in "continuation" sub-dimension the highest mean score belongs to senior preservice teachers. On the other hand, the differences are not meaningful; preservice teachers' self-efficacy beliefs do not differ meaningfully according to their grade. In other words, it can be said that preservice teachers studying in different grades have similar perceptions of their self-efficacy levels. Table 4 shows preservice teachers' mean scores and total mean scores in sub-dimensions "motivation", "persistence", "lack of self-regulation", "lack of curiosity" obtained from Lifelong Learning Tendency Scale.

Table 4.

Preservice Teachers' Tendencies towards Lifelong Learning

\begin{tabular}{lrrr}
\hline Dimension & $\mathbf{N}$ & $\overline{\boldsymbol{x}}$ & $\mathbf{S}$ \\
\hline Motivation & 242 & 29.14 & 4.92 \\
Persistence & 242 & 25.28 & 5.97 \\
Lack of self-regulation & 242 & 29.45 & 5.67 \\
Lack of curiosity & 242 & 39.76 & 9.38 \\
Total self-efficacy & 242 & 123.64 & 20.50 \\
\hline
\end{tabular}

According to descriptive statistics, the scores that can be obtained from "Lifelong Learning Tendency Scale" are as such: minimum 27, maximum 162, scale median 94.50. Table 4 shows that preservice teachers' total mean score in lifelong learning tendency is 123.64. Preservice teachers' total mean score on the scale (123.64) is higher than the scale median (94.5). Accordingly, it can be stated that preservice teachers' tendencies towards lifelong learning are high. As for the statistics regarding sub-dimensions of Lifelong Learning Tendency Scale, it can be seen that preservice teachers' mean scores in sub-dimensions are respectively as such: motivation ( $X=29.14$ ), persistence $(X=25.28)$, lack of self-regulation ( $X=29.45$ ) and lack of curiosity $(X=39.76)$. Since mean scores in total and in sub-dimensions are higher than scale median of sub-dimensions and total scores, it can be assumed that in general preservice teachers are individuals who are open to learning, eager for and curious about gaining new information and skills, decisive against barriers on their way to reach their goals, have tendency towards lifelong learning, and tend to make an effort to organize their learning. 
Table 5.

Distribution of Preservice Teachers' Tendencies Towards Lifelong Learning According to Gender

\begin{tabular}{llrrrrrr}
\hline Dimension & Gender & $\mathbf{N}$ & $\overline{\boldsymbol{x}}$ & $\mathbf{S}$ & $\mathbf{d f}$ & $\mathbf{t}$ & $\mathbf{P}$ \\
\hline Motivation & Female & 202 & 29.25 & 4.97 & 238 & 0.77 & .71 \\
& Male & 40 & 28.60 & 4.72 & & & \\
Persistence & Female & 202 & 25.42 & 6.10 & 238 & 0.85 & .22 \\
& Male & 40 & 24.54 & 5.26 & & & \\
Lack of self-regulation & Female & 202 & 29.66 & 5.72 & 238 & 1.34 & .81 \\
& Male & 40 & 28.35 & 5.32 & & & \\
Lack of curiosity & Female & 202 & 40.06 & 9.59 & 238 & 1.12 & .36 \\
& Male & 40 & 38.24 & 8.23 & & \\
Total self-efficacy & Female & 202 & 124.42 & 20.91 & 238 & 1.32 & .42 \\
& Male & 40 & 119.74 & 18.05 & & & \\
\hline
\end{tabular}

Table 5 shows that female preservice teachers' mean scores in tendencies towards lifelong learning are higher than those of male preservice teachers. Nevertheless, there is no meaningful difference between mean scores in sub-dimensions and total mean scores according to gender. Preservice teachers' tendencies towards lifelong learning do not change according to gender. In other words, female and male preservice teachers have similar perceptions of their tendencies towards lifelong learning.

Table 6.

Distribution of Preservice Teachers' Tendencies Towards Lifelong Learning According to Grade

\begin{tabular}{|c|c|c|c|c|c|c|c|c|c|c|c|}
\hline Dimension & Grade & $\mathbf{N}$ & $\bar{x}$ & $S$ & Source of variance & KT & KO & df & $\mathbf{F}$ & $p$ & Diff. Groups \\
\hline \multirow[t]{5}{*}{ Motivation } & 1. & 70 & 29.47 & 5.16 & Between Groups & 42.25 & 14.08 & 3 & .57 & .63 & - \\
\hline & 2. & 67 & 28.52 & 4.68 & Within Groups & 5813.37 & 24.42 & 238 & & & \\
\hline & 3. & 62 & 29.52 & 4.33 & Total & 5855.63 & & 241 & & & \\
\hline & 4. & 43 & 29.04 & 5.72 & & & & & & & \\
\hline & Total & 242 & 29.14 & 4.92 & & & & & & & \\
\hline \multirow[t]{5}{*}{ Persistence } & 1. & 70 & 25.60 & 5.97 & Between Groups & 126.62 & 42.20 & 3 & 1.18 & .31 & - \\
\hline & 2. & 67 & 24.12 & 5.70 & Within Groups & 8464.78 & 35.56 & 238 & & & \\
\hline & 3. & 62 & 25.91 & 5.94 & Total & 8591.40 & & 241 & & & \\
\hline & 4. & 43 & 25.65 & 6.35 & & & & & & & \\
\hline & Total & 242 & 25.28 & 5.97 & & & & & & & \\
\hline \multirow{5}{*}{$\begin{array}{l}\text { Lack of self- } \\
\text { regulation }\end{array}$} & 1. & 70 & 31.22 & 4.60 & Between Groups & 355.02 & 118.34 & 3 & 3.80 & $.01^{*}$ & Freshmen and \\
\hline & 2. & 67 & 28.15 & 6.23 & Within Groups & 7407.00 & 31.12 & 238 & & & Sophomores \\
\hline & 3. & 62 & 29.33 & 5.66 & Total & 7762.02 & & 241 & & & \\
\hline & 4. & 43 & 28.74 & 5.80 & & & & & & & \\
\hline & Total & 242 & 29.45 & 5.67 & & & & & & & \\
\hline \multirow{5}{*}{$\begin{array}{l}\text { Lack of } \\
\text { curiosity }\end{array}$} & 1. & 70 & 42.11 & 6.93 & Between Groups & 1242.04 & 414.01 & 3 & 4.92 & $.00 *$ & Freshmen and \\
\hline & 2. & 67 & 36.35 & 10.17 & Within Groups & 20006.58 & 84.06 & 238 & & & Sophomores \\
\hline & 3. & 62 & 39.89 & 10.37 & Total & 21248.62 & & 241 & & & \\
\hline & 4. & 43 & 41.09 & 8.84 & & & & & & & \\
\hline & Total & 242 & 39.76 & 9.38 & & & & & & & \\
\hline \multirow[t]{5}{*}{ Total } & 1. & 70 & 128.40 & 18.36 & Between Groups & 4499.05 & & 3 & 3.68 & $.01^{*}$ & \\
\hline & 2. & 67 & 117.16 & 21.25 & Within Groups & 96831.37 & 1499.68 & 238 & & & Freshmen and \\
\hline & 3. & 62 & 124.66 & 20.44 & Total & 101330.42 & 406.85 & 241 & & & Sophomores \\
\hline & 4. & 43 & 124.53 & 20.84 & & & & & & & \\
\hline & Total & 242 & 123.64 & 20.50 & & & & & & & \\
\hline
\end{tabular}

Table 6 shows that regarding preservice teachers' tendencies towards lifelong learning there is a statistically meaningful difference between their scores in "lack of self-regulation", "lack of curiosity", and "total" scores according to grade. The results of Scheffe test revealed that the differences between the scores and mean scores of freshmen and sophomore preservice teachers were not significantly different. In addition, considering mean scores overall, it is seen that the highest mean scores belong to the freshmen preservice teachers while the lowest mean scores belong to sophomore preservice teachers. Based on these results it can be stated that preservice teachers' tendencies towards lifelong learning decrease at their freshmen and at the beginning of sophomore years yet increase again.

The results of Pearson Correlation coefficient, which was conducted in order to reveal if there is a relationship between self-efficacy and tendency towards lifelong learning, are shown in Table 7 below. 
Table 7.

Relationship Between Self-efficacy and Tendency towards Lifelong Learning

\begin{tabular}{|c|c|c|c|c|c|}
\hline $7^{\text {LLT }}$ & Motivation & Persistence & $\begin{array}{l}\text { Lack of self- } \\
\text { regulation }\end{array}$ & Lack of curiosity & $\begin{array}{r}\text { Lifelong } \\
\text { Learning Total }\end{array}$ \\
\hline Starting & $.41^{* *}$ & $.43^{* *}$ & $.36 * *$ & $.38^{* *}$ & $.50 * *$ \\
\hline Not giving up & $.44 * *$ & $.46^{* *}$ & $.27 * *$ & $.29 * *$ & $.45^{* *}$ \\
\hline Continuation & $.24 * *$ & $.29 * *$ & .09 & $.17^{* *}$ & $.25^{* *}$ \\
\hline Total self-efficacy & $.47^{* *}$ & $.50 * *$ & $.35 * *$ & $.38 * *$ & $.53 * *$ \\
\hline
\end{tabular}

As seen in Table 7, there is a medium-rate (0.53), positive, meaningful relationship between preservice teachers' self-efficacy levels and their tendencies towards lifelong learning. Among given variables it is clear that the strongest positive relationship is between "not giving up" dimension of self-efficacy and "persistence" as one of the tendencies towards lifelong learning. Besides, it can be seen that there is no relationship between "continuation" dimension of self-efficacy and "lack of self-regulation" as one of the tendencies towards learning.

Table 8.

Regression Results Regarding the Extent to Which Self-Efficacy Belief Predicts Tendency towards Lifelong Learning

\begin{tabular}{lrrrrr}
\hline Variable & B & Standard Error & $\boldsymbol{\beta}^{2}$ & $\mathbf{t}$ & $\mathbf{P}$ \\
\hline Self-efficacy & 50.64 & 7.54 & .53 & 6.71 & .00 \\
$\mathrm{R}=.54$ & $\mathrm{R}^{2}=.28$ & & & & \\
$\mathrm{~F}=95.84$ & $\mathrm{p}=.00$ & & & & \\
\hline
\end{tabular}

Table 8 shows that self-efficacy belief is a meaningful predictor of tendency towards lifelong learning $\left(\mathrm{R}=.54, \mathrm{R}^{2}=.28, \mathrm{~F}=95.84 ; p<.01\right)$. It can be maintained that $28.00 \%$ of the total variance regarding tendency towards lifelong learning is explained with self-efficacy belief.

\section{Discussion, Conclusion and Implications}

This study aims to determine preservice primary school teachers' self-efficacy levels and their tendencies towards lifelong learning, to reveal if there is a relationship between preservice teachers' self-efficacy levels and their tendencies towards lifelong learning, and to identify the kind of relationship if any.

Findings of the study show that preservice teachers' total mean score of self-efficacy is 62.70. Preservice teachers' mean scores on the self-efficacy scale are higher than scale median (51). Regarding self-efficacies, preservice teachers' mean scores in sub-dimensions "starting", "not giving up", "continuation" are slightly higher than scale median. It can be assumed that preservice primary school teachers' academic self-efficacy beliefs are high in general. This finding overlaps with the findings of some other researches (Oğuz, 2009; Yılmaz, Gürçay \& Ekici, 2007).

Male preservice teachers' self-efficacy levels were found to be slightly higher than those of female preservice teachers. However, "t test" reveals that the difference is not meaningful and that neither preservice teachers' self-efficacy levels nor the gender differences have an effect on their self-efficacy levels. This finding matches with the findings of several other studies (Altuncekiç, Yaman \& Koray, 2005; Azar, 2010; Çetin, 2007; Ekici, 2008; Saracoğlu, 2018; Saracaloğlu, Karasakaloğlu \& Evin-Gencel, 2010; Şensoy \& Aydoğdu, 2008; Taşkın \& Hacıömeroğlu, 2010; Uysal, 2013; Yenice, 2012; Yıldırım \& İlhan, 2010). Nevertheless, there are studies whose findings reveal that self-efficacy perceptions differ according to gender (Aypay, 2010; Britner \& Pajares, 2006; Ekici, 2005). For example, in their studies Bong (1999) and Durdukoca (2010) found that male preservice teachers have higher self-efficacy levels that those of female preservice teachers. On the other hand, Shahid and Thompson (2001), and Yenilmez and Kakmacı (2008) found that female preservice teachers' self-efficacy levels are higher than those of male preservice teachers. As a result, these studies revealed that self-efficacy levels differs according to gender and that the difference may be in favour of male or female preservice teachers. Taking these studies into consideration, it can be stated that there is no consistency regarding the finding that self-efficacy differs according to gender. Such an inconsistency may have resulted from the differences between participant groups, the scales used and the time of the research. The finding of this study 
which reveals no difference in terms of gender variable may lead to the thought that both male and female preservice teachers benefit from their education at similar rates and they develop their skills.

The findings of the study also indicate that preservice teachers' self-efficacy levels do not differ according to grade. There are studies whose findings overlap with those of this study (Berkant \& Ekici 2007; Cerit, 2010; Uysal, 2013; Yenice, 2012). On the other hand, studies carried out by some researchers (Altunçekiç et. al., 2005, Durdukoca, 2010; Kozcu et. al., 2007; Yenilmez \& Kakmacı 2008) reveal differences between preservice teachers' self-efficacy levels according to their grades. This finding can be interpreted as experiences in studying not contributing to preservice teachers' self-efficacy beliefs, and that such experiences do not make preservice teachers' self-efficacy beliefs stronger.

According to the findings of the study, preservice teachers' total mean scores on Lifelong Learning Tendency Scale and their scores in sub-dimensions are higher than scale median. Relevant studies have different findings about this. While some studies (Ayra, 2015; Demirel \& Akkoyunlu 2010; Ergun \& CömertÖzata, 2016; Gür-Erdoğan, 2014) found that preservice teachers' tendencies towards lifelong learning was high, others found preservice teachers' tendencies towards lifelong learning as low (Diker-Coşkun \& Demirel, 2012; Karakuş, 2013; Kılıç, 2014; Savuran, 2014; Şahin et. al., 2010; Tunca, Alkın Şahin \& Aydın, 2015). It can be maintained that preservice teachers are decisive in and curious about joining, organizing and sustaining activities for lifelong learning. In other words, preservice teachers were found to be eager for learning and developing themselves continuously. Kara and Kurum (2007) state that preservice primary school teachers regard lifelong learning as important and necessary. Yet, the level obtained needs to be increased.

Analysis of preservice teachers' tendencies towards lifelong learning according to gender difference shows that female preservice teachers' mean scores are higher than those of male preservice teachers. However, total mean scores and mean scores in sub-dimensions do not differ meaningfully according to gender. It was found that preservice teachers' tendencies towards lifelong learning do not differ according to gender. Therefore, male and female preservice teachers' tendencies towards lifelong learning are similar. There are other studies (Dündar, 2016; Oral \& Yazar, 2015; Savuran, 2014; Şahin, Akbaşlı \& Yanpar-Yelken, 2010) which support the results of this study. Nevertheless, there are also studies which found meaningful difference according to gender. Some of these studies (Demirel \& Akkoyunlu, 2010; Diker-Coşkun, 2009; Evin-Gencel, 2013; i̇zci \& Koç, 2012; Karakuş, 2013) reveal that female preservice teachers have higher levels of tendencies towards lifelong learning while others (Diker-Coşkun \& Demirel, 2012; Eksioğlu, Tarhan \& Gündüz-Çetin, 2017) found that male preservice teachers have higher levels of tendencies towards lifelong learning. According to Diker-Coşkun and Demirel (2012), who found female preservice teachers' tendencies towards lifelong learning higher than the male teachers' in their study, explained it to be due to socially constructed gender roles women wish to gain and desire to be successful in their jobs. On the other hand, Ekşioğlu, Tarhan and GündüzÇetin (2017), state that male preservice teachers having higher levels of tendencies towards lifelong learning may result from various opportunities culturally presented to men for their education. The fact that there are different results in different studies may be explained with variety in research tools and participants. The finding that there is a meaningful difference between tendencies towards lifelong learning may be a result of the fact that all preservice teachers regard lifelong learning as an important part of teaching profession.

It can be maintained that overall preservice teachers' tendencies towards lifelong learning according to grade are at high levels. In sub-dimensions "motivation" and "persistence", preservice teachers" tendencies towards lifelong learning do not differ meaningfully according to grade. However, it is seen that there are statistically meaningful differences between "lack of self-regulation", "lack of curiosity" and "total" scores. It was found that these differences resulted from mean scores of freshmen and sophomore preservice teachers, and that there is no statistically meaningful difference between mean scores of participants studying in other grades. Thus, it can be pointed out that freshmen preservice teachers' tendencies towards lifelong learning are higher. Relying on the findings it can be stated that preservice teachers' tendencies towards lifelong learning decrease when they are freshmen and when they become sophomores, later on their tendencies increase again, but this increase is not higher than mean scores of freshmen preservice teachers. In their studies Oral and Yazar (2015) found meaningful difference on behalf of junior preservice teachers; Eksioğlu, Tarhan and Gündüz-Çetin (2017) found meaningful difference on behalf of sophomore preservice teachers; Demirel and Akkoyunlu (2010) found meaningful difference on behalf of senior preservice teachers.

On the other hand, Diker-Coşkun (2009) found no meaningful difference between preservice teachers' mean scores of tendencies towards lifelong learning according to grade. It is expected that as the grade level 
gets higher, tendencies towards lifelong learning will get higher during university education. It can be interpreted from the results that preservice teachers' tendencies towards lifelong learning are influenced more by their personal characteristics than by the university education they get. Moreover, preservice teachers' tendencies towards lifelong learning do not change in a positive way in line with academic education they get for four years, and freshmen preservice teachers' tendencies towards lifelong learning were found higher than participants from other grades. Developing skills for lifelong learning during university education is related to academic guidance, social-cultural environment and adequacy of institutional facilities (Darwin \& Palmer, 2008; Wenger, 2002). Wenger (2002) emphasizes that when university students are guided by effective supervisors, a kind of social learning system can be created, and guidance process needs to be regarded as a factor which affects students' intellectual and professional development and completes university education. Darwin and Palmer (2008) suggest that academic supervisors not only guide students academically but they also enable the students to gain skills to learn and raise awareness of lifelong learning.

Another finding of the study is that there is a meaningful relationship between preservice teachers' selfefficacy levels and their tendencies towards lifelong learning. A low-level, positive relationship was identified between the two variables. It can be predicted that preservice teachers' tendencies towards lifelong learning will increase when their self-efficacy levels increase. Results of the analysis reveal that self-efficacy belief is a meaningful predictor of tendency towards lifelong learning.28\% of the total variance regarding tendencies towards lifelong learning is explained with self-efficacy belief. Relevant studies indicate that self-efficacy belief is a good, meaningful predictor of teachers' behaviours and several positive practices in teaching (Gibson \& Dembo, 1984; Goddard et.al., 2004). Teachers whose efficacy levels are high have high academic standards, the most important of which is tendency towards lifelong learning. Teachers with high levels of self-efficacy concentrate more on their profession, they make an effort for their scientific development (Schmitz, 2000), their motivation is higher, they are patient, they have self-regulation, they are curious about innovations and open to learning, they are more eager for and enthusiastic about teaching (Bıkmaz, 2004), and these characteristics belong to individuals who are open to lifelong learning. In that sense, the basic principle of enhancing teachers' self-efficacy perceptions and their tendencies towards lifelong learning is related with improving the quality of education they get as preservice teachers.

Higher education institutions have an important role in enhancing social welfare and quality of life. Therefore, in order for lifelong learning to be put into practice, curriculum in higher education needs to be developed with activities through which students can control their learning and take responsibilities for research (Appley, 2001; Coşkun \& Demirel,2012). According to Parkinson (1999), in order to train individuals to be competent lifelong learners, curriculum of higher education should include out-of-class activities and active learning methods through which students will be able to take responsibility of their own learning. Students should be taught to learn, manage their own educational process and be involved in problems, and encouraged to make self-evaluations. To conclude, when learning environments are being developed in higher education institutions in Turkey, particularly in the faculty of education, academic and socio-cultural programs where individuals' self-efficacy and tendency towards lifelong learning improve should be organized and learning environments should be created accordingly. It should always be remembered that teachers have an important role in bringing up individuals who are "lifelong learners". Education of preservice teachers needs to be conducted with learner-centered programs which will contribute to preservice teachers' self-efficacy and their personal and social development including necessary knowledge and skills in order to raise individuals who are lifelong learners. 


\section{TÜRKÇE SÜRÜM}

\section{Giriş}

Hızlı değişim gösteren, çoğalan bilginin aynı hızla yayılması toplumsal hayatları dolayısıyla bireylerden beklenen nitelikleri sürekli etkilemektedir. Bireylerin bilgi, tutum, amaç ve beklentilerinin değiştiği bu süreçte formal eğitimden beklenen bireylerin ihtiyaçlarına cevap verecek şekilde yapılandırılmasıdır. Toplumun kültürünü aktarmak ve geliştirmek, bireylerin sosyalleşmesini sağlamak, nitelikli davranış ve beceri kazandırarak onları yetiştirmekle yükümlü formal eğitim kurumlarının, sürekli değişen ihtiyaçları karşılayabilmesi ve işlevlerini yerine getirebilmesi ise eğitim sistemlerine ve bu sistemi hayata geçirecek, uygulamaları ile yön verecek öğretmenlere bağlıdır. Zira eğitim ve öğretim sisteminin girdileri olarak değerlendirilen; eğitim-öğretim programları, öğretim materyalleri, sunulan teknolojik alt yapı ve sahip olunan fiziksel donanım öğelerinin öğrenmeye etkin bir şekilde katkı sağlaması öğretmenlerin yeterlik düzeyinden etkilenmektedir. Öğretmenlerin yeterlik düzeyleri, genel kültürleri, öğretmen meslek bilgileri ve alan bilgisi bakımından nitelikli yetişmiş olmalarının yanı sıra görev ve sorumluluklarını gerçekleştirebilme niteliklerine ilişkin öz yeterlik algılarını kapsar (Ay, 2007; Şahin, 2010).

Bandura Sosyal Bilişsel Kuram'da öz yeterlik kavramını bireyin belli bir görevi başlatıp sonuç alıncaya kadar sürdürebileceğine ilişkin kendine yönelik inancı ve güveni olarak tanımlamıştır (Bandura, 1994; Bandura, 1997; Golightly, 2007). Bandura'ya göre (1994) öz yeterlik kişilerin yaşamlarını yönetme, sorunları çözümleme, bir görevi yerine getirmek için gerekli olan bilişsel, psiko-motor, sosyal davranışları ne düzeyde gerçekleştirebileceklerine ilişkin kişisel algılamaları ve kendilerine ilişkin yargılarıdır. Öz yeterlik düzeylerine ilişkin algıları yüksek olan kişiler becerilerine, ortaya koydukları ürünlere güvenirler bunlar için gayretlidirler ve karşılaştıkları olumsuzlukları değiştirebilirler (Carver \& Scheier, 2003; Pajares, 2002).

Eğitim alanında öğretmen öz yeterlik inancı, öğretmenin performansı ve öğretimin etkililiğindeki başarısı ile ilişkilidir. Ancak öz yeterlik inancı öğretmenin alan ve mesleki yetersizliklerini gideren bir özellik olmaktan ziyade öğretmenin performans düzeyini biçimlendiren ve yükselten itici bir güçtür (Goddard, Hoy \& WoolfolkHoy, 2000; Tschannen-Moran \& Woolfolk-Hoy, 2001). Zira öz yeterlik kişinin sahip olduğu özelliklere işaret etmez, sahip olduğu özelliklere ilişkin kendini algılaması ve inanması durumudur (Akkoyunlu, Orhan \& Umay, 2005; Leithwood, 2007).

Pek çok araştırmada yeterlik düzeyi yüksek olan öğretmenlerin; meslek standartlarının yüksek olduğu, daha planlı, organize olmuş öğretimi tercih ettikleri, yenilikçi, öğrenci merkezli, sınıf yönetiminde becerikli, iletişimde etkin, öğrenciyi teşvik eden, ihtiyaçlara odaklı, insancıl yaklaşımı tercih eden ve öğretimde pek çok yöntem ve teknikten yararlanan kişiler olduğu belirtilmektedir (Balcı, 2001; Özenoğlu-Kiremit, 2006; Woolfolk \& Hoy, 1990). Öğretmenlerin öz yeterlik algılarının yüksek olması öğretim uygulamalarında istek ve çabalarını artırmakta, performanslarını etkilemekte (Bıkmaz, 2004; Goddard et. al., 2000) bu durum da öğrenci öğrenmesine ve başarısına olumlu yönde katkı getirmektedir (Goddard, 2001, 2004; Tschannen-Moran \& Hoy, 2001). Ayrıca Schmitz (2000), öz yeterlik düzeyinin yüksek olmasının mesleğin getirdiği olumsuzluklar ve stres ile baş edebilme durumunu da artırdığını, bu öğretmenlerin engellerle sorunlarla daha rahat baş edebildiklerini ve gerekli kararları hızı bir şekilde alarak öğretimlerine devam ettiğini belirtmektedir(Cited by Yılmaz et. al., 2004).

Kendine güvenli, ihtiyaçları ve yapabilecekleri konusunda farkında olan, kendine ilişkin beklentisi kısaca öz yeterliği yüksek bireylerin yetkinlik ve yüksek performans sergileme çabası yaşam boyu öğrenme eğilimlerini artırmaktadır (Schunk, 1996).Yaşam boyu öğrenme bireyin hayatı boyunca öğrenme ihtiyacı, isteği ve bilinci içinde olması, öğrenmeye ilişkin tutum ve alışkanlık kazanarak öğrenmeyi yaşamının bir parçası haline getirmedir.

Yaşam boyu öğrenme; bireyin bilgi, beceri, farkındalık ve yeterliliklerini geliştirmek, niteliğini artırmak için katıldığı her türlü öğrenme faaliyetini kapsar (Akkoyunlu, 2008; Ersoy \& Yılmaz, 2005; HBÖ, 2009; Turan 2005) ve bu öğrenme faaliyetleri hayatın bütününde yer alır (Diker-Coşkun \& Demirel, 2012). Shuman vd. de (2005) yaşam boyu öğrenmeye ait becerileri; bilgi teknolojilerinde yetkin olma, üst düzey düşünme becerisi, ihtiyacı olan doğru bilgiye ulaşma ve kullanma, öz denetimli olma, değişim ve yeniliklere uyum sağlama, öğrenmede isteklilik, öğrenme planı ve stratejisi oluşturarak bu planı izleme şeklinde ifade etmişlerdir. 
Yaşam boyu öğrenen kendi öğrenimini planlayabilir ve değerlendirebilir; aktif öğrenici olarak hem okul hem de okul dışı ortamlarda farklı konu alanlarından elde edilen bilgileri entegre ederek hayatta yol alabilir (Knapper \& Cropley 2000). Yaşam boyu öğrenmeye yönelik birey bilimsel yenilikler, toplumsal gelişmeler, değişen uygulamalara karşı ilgili (Akkoyunlu, 2008), güdülenmiş, sebatlı, meraklı ve öğrenmesini düzenleyebilen kişidir (Diker-Coşkun \& Demirel, 2012). Ayrıca yaşam boyu öğrenmenin ekonomik bir hareket, yaşlanmakta olan nüfusun yeni çalışma ve yaşama koşullarına uyumunu arttırma planı ve bir küreselleşme hareketi olduğunu vurgulayan açıklamalar da vardır. Örneğin Aspin ve Chapman’a (2001) göre yaşam boyu öğrenmenin amacı, bireysel gelişimi sağlayarak toplumu daha verimli hale getirmek ve ekonomik kalkınmayı hızlandırmaktır. Türkiye'de de yaşam boyu öğrenme amaçları sekizinci beş yıllık kalkınma planı kapsamında benzer ifadelerle; "bireylerin kişisel gelişimini sağlamak, toplumsal bütünleşme ve ekonomik büyümeyi gerçekleştirmek" (DPT, 2001, p. 10) şeklinde vurgulanmaktadır.

Yaşam boyu öğrenme becerilerinin erken yaşlardan itibaren kazandırılmasında eğitim sistemleri ve öğretmen kilit rol oynamaktadır (Akkoyunlu, 2008). Selvi (2011) öğretmenlerin yaşam boyu öğrenmeye yönelik yeterliklerinin iki boyutta ele alınması gerektiğini belirtmiştir, birinci boyut öğretmenlerin kendilerinin yaşam boyu öğrenen bireyler olmaları, ikincisi ise öğrencilerinin yaşam boyu öğrenme becerilerini geliştirmesinden sorumlu olmalarıdır. Mesleğin gereği olarak öğretmenler, yenilenen nesille birlikte, oluşan ihtiyaçlara yönelik yenilikleri takip etmek, toplumsal gelişmelerin farkında olmak, kendilerini sürekli geliştirmek yaşam boyu öğrenme becerilerine sahip olmak durumundadırlar. Öğretmenlerin öğrenme isteği, bilinci, tutumu ve alışkanlıklarını edindirmesi kısaca yaşam boyu öğrenme anlayışını kazandırması bireyleri formal eğitim sonrası yıllarda da gelişmelere uyum sağlayan, yeterliklerini artırabilen nitelikte yetiştirmesi hem bireysel hem de toplumsal kalkınmayı sağlamada önemlidir.

Bu bağlamda öğretmenlerin daha mesleğe başlamadan öz yeterlik inançları ve yaşam boyu öğrenme eğilimlerinin belirlenmesi ve varsa yetersizliklerinin giderilmesi toplumu oluşturan bireylerin öz yeterliği yüksek, yaşam boyu öğrenen bireyler yetiştirmemize dolayısıyla toplumsal faydaya katkı sağlayacaktır.

\section{Araştırmanın Amacı}

Araştırmanın temel amacı, sınıf öğretmen adaylarının öz yeterlik düzeyi ile yaşam boyu öğrenme eğilimlerinin; cinsiyet ve sınıf düzeyine göre anlamlı bir şekilde farklılaşıp farklılaşmadığını belirlemek ve öz yeterlik düzeyi ile yaşam boyu öğrenme eğilimleri arasında anlamlı bir ilişkinin olup olmadığını ortaya koymaktır. Bu amaç doğrultusunda aşağıdaki sorulara cevap aranmıştır.

1. Öğretmen adaylarının öz yeterlikleri ne düzeydedir?

2. Öğretmen adaylarının öz yeterlik düzeyleri cinsiyetlerine göre farklılık göstermekte midir?

3. Öğretmen adaylarının öz yeterlik düzeyleri sınıflarına göre farklılık göstermekte midir?

4. Öğretmen adaylarının yaşam boyu öğrenme eğilimleri ne düzeydedir?

5. Öğretmen adaylarının yaşam boyu öğrenme eğilimleri cinsiyetlerine göre farklılık göstermekte midir?

6. Öğretmen adaylarının yaşam boyu öğrenme eğilimleri sınıflarına göre farklılık göstermekte midir?

7. Öğretmen adaylarının öz yeterlik düzeyi ile yaşam boyu öğrenme eğilimleri arasında anlamlı bir ilişki var midır?

8. Öğretmen adaylarının öz yeterlik düzeyi, yaşam boyu öğrenme eğilimlerini yordamakta mıdır?

\section{Yöntem}

\section{Araştırmanın Modeli}

Araştırma, tarama modellerinden ilişkisel tarama modeline dayalıdır. Tarama modelleri geçmişte ya da halen var olan bir durumu var olduğu şekliyle betimlemeyi amaçlar (Karasar, 2013).

\section{Örneklem}

Araştırmanın örneklemini Gazi Üniversitesi Gazi Eğitim Fakültesi'nde öğrenim gören 242 sınıf öğretmeni adayı oluşturmaktadır. Örneklem belirlenirken uygun örnekleme yönteminden yararlanılmıştır. Uygun örneklemede (kolay ulaşılabilir örnekleme) araştırmacıya yakın, araştırma için uygunluk ve gönüllülük gösteren, katılımcılarına ulaşması kolay kişilerle çalışılmaktadır (Gravetter \& Forzano, 2012). 242 öğretmen adayından oluşan örneklemin 202'si kadın, 40'ı erkek öğretmen adayıdır. Öğretmen adaylarının 70'i birinci sınıf, 67'si ikinci sınıf; 62'si üçüncü sınıf; 43'ü de dördüncü sınıfta öğrenim görmektedir. 


\section{Veri Toplama Aracı}

Çalışmada "öz yeterlik ölçeği" ve "yaşam boyu öğrenme eğilimleri ölçeği" olmak üzere iki ayrı veri toplama aracı kullanılmıştır. Kullanılan "öz yeterlik ölçeği" Sherer vd. (1982) tarafından geliştirilmiş, Yıldırım ve ilhan (2010) tarafından Türkçeye uyarlanmıştır. "Sizi ne kadar tanımlıyor?" sorusuna "hiç" ve "çok iyi" aralığında değişen seçeneklerin sunulduğu ölçek beşli likert dereceleme ile yapılandırılmıştır. Yapılan doğrulayıcı faktör analizi sonucunda üç faktör olarak belirlenen ölçek sırasıyla; "başlama", "yılmama" ve "sürdürme çabası-ısrar" boyutlarından oluşmaktadır. 17 maddeden oluşan ölçeğin Cronbach Alfa güvenirlik katsayısı Yıldırım ve illhan (2010) tarafından $\alpha=.80$ ' olarak bulunmuştur. Ölçeğin bu araştırmada Cronbach Alpha güvenirlik katsayısı $\alpha=.85$ hesaplanmıştır. Yararlanılan "Yaşam Boyu Öğrenme Eğilimleri Ölçeği" ise Coşkun-Diker (2009) tarafından geliştirilmiştir. Ölçek "çok uyuyor", "kısmen uyuyor", "çok az uyuyor", "çok az uymuyor", "kısmen uymuyor", "hiç uymuyor" şeklinde altılı likert dereceleme ile hazırlanmıştır. Yaşam boyu öğrenen özelliklerini olumluolumsuz yönde ele alan 27 maddeli ölçek sırasıyla; "güdülenme", "sebat" "öğrenmeyi düzenlemede yoksunluk" ve "merak yoksunluğu" olmak üzere dört alt boyuttan oluşmaktadır. Ölçeğin Cronbach Alpha güvenirlik katsayısı ise $\alpha=.89$ 'dur (Coşkun-Diker, 2009). "Yaşam boyu öğrenme eğilimleri ölçeği”nin bu çalışmadaki Cronbach Alpha güvenirlik katsayısı ise $\alpha=.91$ bulunmuştur.

\section{Verilerin Çözümlenmesi}

Elde edilen verilerle sınıf öğretmeni adaylarının öz yeterlik ve yaşam boyu öğrenme eğilimleri cinsiyet ve sınıf düzeylerine göre betimlenmiş, öz yeterlik inançları ve yaşam boyu öğrenme eğilimlerinin cinsiyet ve sınıf düzeylerine göre farklılaşıp farklılaşmadığı incelenmiştir. İstatistiksel olarak, betimleme için öğretmen adaylarının öz yeterlik ve yaşam boyu öğrenme eğilimlerine ilişkin toplam ortalama puanlar, standart sapmalar hesaplanmış ve her bir ölçeğin uygulanması ile alınabilecek minimum, orta ve maksimum puanlar ölçüt olarak alınmıştır. Her iki ölçeğe ilişkin ölçek ortanca puanları sonuçların normal dağılım gösterdiği sayıltısına dayalı olarak hesaplanmıştır.

17 maddelik öz yeterlik ölçeğinde seçenekler 5’li likert tipinde ve 1“hiç"-5 "çok iyi” aralığındadır. 3 değeri "orta” nokta kabul edilmiştir. Ölçekten alınabilecek minimum puan 17; ortanca puanı 51; ve maksimum puan 85 olarak belirlenmiştir. Öz yeterlik ölçeği alt boyutlarına ilişkin puanlama dağılımı;

- 9 maddeden oluşan "Başlama” boyutundan alınabilecek puanlar, minimum9; ortanca27; maksimum45'dir.

- 5 maddeden oluşan "Yılmama” boyutundan alınabilecek puanlar, minimum 5; ortanca 15; maksimum 25'tir.

- 3 maddeden oluşan "Sürdürme" boyutundan alınabilecek puanlar, minimum 3; ortanca 9; maksimum 15'dir.

27 maddelik "Yaşam Boyu Öğrenme Eğilimi" ölçeğinde seçenekler 6’lı likert tipinde ve 1 ila 6 aralığındadır ve 3,5 değeri "çok az uyuyor ile "çok az uymuyor" değerlerinin orta noktası olarak kabul edilmiştir. Ölçekten alınabilecek minimum puan 27, ortanca puanı 94,5 ve maksimum puan 162 olarak belirlenmiştir. Dört alt boyuttan oluşan yaşam boyu öğrenme eğilimi ölçeğinin alt boyutlara ilişkin puan dağılımı;

- 6 maddeden oluşan "Güdülenme" boyutundan alınabilecek puanlar, minimum 6; ortanca 21; maksimum $36^{\prime}$ dır.

- 6 madde oluşan "Sebat" boyutundan alınabilecek puanlar minimum 6; ortanca 21; maksimum 36'dır.

- 6 madde oluşan “Öğrenmeyi Düzenleme" boyutundan alınabilecek puanlar minimum 6; ortanca 21; maksimum 36'dır.

- 9 madde oluşan "Merak Yoksunluğu" boyutundan alınabilecek puanlar minimum 9; ortanca 31.5; maksimum 54'tür.

Elde edilen veriler bir katılımcı "tutum puanının" ölçekleme boyutunun ortalarında bir yere düşmesi bu kişinin tutumunun orta veya tam oluşmadığı şeklinde (Turgut \& Baykul, 1992) ifade edilebilirliğinden yola çıkılarak yorumlanmıştır. Araştırmada değişkenlere dayalı olarak yapılacak analizler öncesinde veri setinin parametrik test koşullarını sağlayıp sağlamadığı Kolmogorov-Smirnov testi (Büyüköztürk, 2007) ile kontrol edilmiştir. Kolmogorov-Smirnov testi $p$ değerinin p >.05 ten büyük çıkması, dağılımın normal dağılımdan anlamlı bir farklıık sergilemediği, normal dağılıma uygun olduğu şeklinde yorumlanır (Büyüköztürk,2007). Kontroller sonrasında dağılımın parametrik test koşullarını sağladığı sonucuna varılmıştır. Öz yeterlik ve yaşam boyu öğrenme eğilimlerinin cinsiyete göre karşılaştırılmasında t testi, sınıf düzeyine göre karşılaştırılmasında tek yönlü varyans analizi (ANOVA) kullanılmıştır. Tek yönlü varyans analizinde (ANOVA) anlamlı fark bulunması 
durumunda farkın kaynağı Scheffe testi ile incelenmiştir. Öğretmen adaylarının öz yeterlik düzeyi ile yaşam boyu öğrenme eğilimleri arasında doğrusal bir ilişki olup olmadığını belirlemek için Pearson Moment çift yönlü korelasyon analizi $(r)$ ve yordayıc değişkenin (öz yeterlik düzeyi) yordanan değişkeni (yaşam boyu öğrenme eğilimi) tahmin etme gücünün belirlenmesi için basit regresyon analizi tekniklerinden yararlanılmıştır.

\section{Bulgular}

Bu bölümde, araştırmanın alt problemleri doğrultusunda elde edilen bulgular sunulmuştur. Sırasıyla sınıf öğretmenliği adaylarının öz yeterlik düzeyleri, öz yeterlik düzeylerinin cinsiyete ve sınıf düzeyine göre anlamlı bir şekilde farklılaşıp farklılaşmadı̆̆ı; adayların yaşam boyu öğrenme eğilimleri, yaşam boyu öğrenme eğilimlerinin cinsiyete ve sınıf düzeyine göre anlamlı bir şekilde farklılaşıp farklılaşmadığı; öz yeterlik düzeyi ile yaşam boyu öğrenme eğilimleri arasında anlamlı bir ilişkinin olup olmadığına yer verilmiştir.

Tablo1.

Öğretmen Adaylarının Öz-yeterlik Düzeyleri

\begin{tabular}{llrr}
\hline Boyut & $\mathbf{N}$ & $\overline{\boldsymbol{x}}$ & \\
\hline Başlama & 242 & 33.60 & $\mathbf{S}$ \\
Yılmama & 242 & 18.44 & 3.53 \\
Sürdürme & 242 & 10.62 & 1.92 \\
ÖY Toplam & 242 & 62.70 & 9.40 \\
\hline
\end{tabular}

Tablo 1'de, öğretmen adaylarının "başlama", yılmama”, "sürdürme" alt boyutlarında ve toplam öz yeterlik düzeyi ortalama puan dağılımları görülmektedir. Öğretmen adaylarının öz yeterlik toplam puan ortalaması 62.70'dir. Adayların öz yeterlik ölçeğinden aldıkları puanların ortalaması ölçek orta puanının (51) üstündedir. Adayların öz yeterliklerine ilişkin "başlama", "yılmama" "sürdürme" alt boyutları ortalama puanları alınabilecek ölçek orta puanından az da olsa yüksek çıkmıştır. Buna göre öğretmen adaylarının öz yeterlik düzeylerinin yüksek olduğu söylenebilir. Tablo 2'de öğretmen adaylarının cinsiyete göre öz yeterlik düzeylerinin farklılaşıp farklılaşmadığı incelenmiştir

Tablo2.

Öğretmen Adaylarının Öz-yeterlik DüzeylerininCinsiyete Göre Dağıımı

\begin{tabular}{llrrrrrr}
\hline Boyut & Cinsiyet & $\mathbf{N}$ & $\overline{\boldsymbol{X}}$ & $\mathbf{S}$ & $\mathbf{s d}$ & $\mathbf{t}$ & $\mathbf{P}$ \\
\hline Başlama & Kadın & 202 & 33.62 & 5.88 & 238 & .00 & .97 \\
& Erkek & 40 & 33.61 & 5.67 & & & .87 \\
Yılmama & Kadın & 202 & 18.35 & 3.56 & 238 & & .68 \\
& Erkek & 40 & 18.89 & 3.38 & & & .09 \\
Sürdürme & Kadın & 202 & 10.54 & 1.96 & 238 & 1.43 & .61 \\
& Erkek & 40 & 11.02 & 1.68 & & & .55 \\
& Kadın & 202 & 62.53 & 9.61 & 238 & & .61 \\
& Erkek & 40 & 63.53 & 8.35 & & & \\
\hline
\end{tabular}

Tablo 2'de görüldüğü gibi erkek öğretmen adayların “yılmama”, “sürdürme” ve "toplam” öz yeterlik düzeylerine ilişkin ortalama puanları, kadınlara göre çok az farkla yüksek bulunmuştur. Ancak gerek ölçeğin alt boyutları gerekse bütünü açısından ele alındığında öğretmen adaylarının öz yeterlik düzeyinin cinsiyete göre anlamlı biçimde farklılaşmadığı görülmektedir. Başka bir deyişle kadın ve erkek öğretmen adayları öz yeterliklerine ilişkin benzer algılara sahiptirler.

Tablo 3'e göre "başlama", "yılmama" ve toplam" puan ortalamaları dikkate alındığında, en yüksek ortalamanın çok az farkla 1. sınıf öğretmen adaylarına, "sürdürme" alt boyutunda ise 4. sınıf öğretmen adaylarına ait olduğu görülmektedir. Bununla birlikte elde edilen farklar anlamlı değildir yani öğretmen adaylarının öz yeterlik inançları sınıf düzeyine göre anlamlı bir şekilde farklılaşmamaktadır. Diğer bir deyişle farklı sınıf düzeylerinde olan öğretmen adaylarının öz-yeterlik düzeylerine ilişkin benzer algılara sahip olduğu söylenebilir. Tablo 4'de, öğretmen adaylarının yaşam boyu öğrenme eğilimleri ölçeğinden elde edilen; "motivasyon", "sebat", “öğrenmeyi düzenlemede yoksunluk", "merak yoksunluğu” alt boyutları ortalama puanları ve toplam puan ortalamaları yer almaktadır. 
Tablo.3

Öğretmen Adaylarının Öz-yeterlik Düzeylerinin Sınıflara Göre Dağııımı

\begin{tabular}{|c|c|c|c|c|c|c|c|c|c|c|}
\hline Boyut & Sinıf & $\mathbf{N}$ & $\bar{x}$ & $S$ & Varyans Kaynağı & KT & KO & Sd & $\mathbf{F}$ & p \\
\hline \multirow[t]{5}{*}{ Başlama } & 1. & 70 & 35.03 & 5.88 & Gruplar Arası & 347.62 & 115.87 & 3 & 3.50 & .01 \\
\hline & 2. & 67 & 32.40 & 5.67 & Gruplar içi & 7863.67 & 33.041 & 238 & & \\
\hline & 3. & 62 & 32.62 & 5.86 & Toplam & 8211.29 & & 241 & & \\
\hline & 4. & 43 & 34.66 & 5.45 & & & & & & \\
\hline & Toplam & 242 & 33.62 & 5.83 & & & & & & \\
\hline \multirow[t]{5}{*}{ Yılmama } & 1. & 70 & 19.23 & 3.54 & Gruplar Arası & 64.38 & 21.46 & 3 & 1.73 & .16 \\
\hline & 2. & 67 & 18.15 & 3.07 & Gruplar içi & 2943.40 & 12.36 & 238 & & \\
\hline & 3. & 62 & 17.95 & 3.63 & Toplam & 3007.79 & & 241 & & \\
\hline & 4. & 43 & 18.32 & 3.93 & & & & & & \\
\hline & Toplam & 242 & 18.44 & 3.53 & & & & & & \\
\hline \multirow[t]{5}{*}{ Sürdürme } & 1. & 70 & 10.49 & 2.31 & Gruplar Arası & 3.53 & 1.17 & 3 & .31 & .81 \\
\hline & 2. & 67 & 10.56 & 1.69 & Gruplar içi & 890494 & 3.74 & 238 & & \\
\hline & 3. & 62 & 10.79 & 1.89 & Toplam & 894.02 & & 241 & & \\
\hline & 4. & 43 & 10.69 & 1.64 & & & & & & \\
\hline & Toplam & 242 & 10.62 & 1.92 & & & & & & \\
\hline \multirow[t]{5}{*}{ OY Toplam } & 1. & 70 & 64.76 & 10.25 & Gruplar Arası & 612.58 & 204.19 & 3 & 2.34 & .07 \\
\hline & 2. & 67 & 61.12 & 8.40 & Gruplar içi & 20716.17 & 87.04 & 238 & & \\
\hline & 3. & 62 & 61.38 & 9.30 & Toplam & 21328.76 & & 241 & & \\
\hline & 4. & 43 & 63.69 & 9.14 & & & & & & \\
\hline & Toplam & 242 & 62.70 & 9.40 & & & & & & \\
\hline
\end{tabular}

Tablo 4.

Öğretmen Adaylarının Yaşam Boyu Öğrenme Eğilimleri

\begin{tabular}{lrrr} 
Boyut & $\mathbf{N}$ & $\overline{\boldsymbol{X}}$ & $\mathbf{S}$ \\
\hline Motivasyon & 242 & 29.14 & 4.92 \\
Sebat & 242 & 25.28 & 5.97 \\
Öğrenmeyi Düzenleme Yoksunluğu & 242 & 29.45 & 5.67 \\
Merak Yoksunluğu & 242 & 39.76 & 9.38 \\
YB Toplam & 242 & 123.64 & 20.50 \\
\hline
\end{tabular}

Betimsel istatistiklerin incelenmesine göre "Yaşam Boyu Öğrenme Eğilimleri Ölçeği”"nden alınabilecek en düşük puan 27, en yüksek puan 162, ölçek ortalaması 94,5 dir.Tablo4'te görüldüğü gibi öğretmen adaylarının yaşam boyu öğrenme eğilimi toplam puan ortalaması 123.64 'dür. Öğretmen adaylarının ölçekten aldıkları toplam puan ortalaması(123.64), ölçeğin ortanca puanından(94.5)yüksek bulunmuştur. Buna göre öğretmen adaylarının yaşam boyu öğrenme eğilimlerinin yüksek olduğu söylenebilir. Yaşam boyu öğrenme ölçeği alt boyutlarına ilişkin istatistikler incelendiğinde; öğretmenlerin alt boyutlara ilişkin puan ortalamalarının sırasıyla güdülenme $(X=29.14)$, sebat $(X=25.28)$, öğrenmeyi düzenlemede yoksunluk $(X=29.45)$ ve merak yoksunluğu $(X$ $=39.76)$ olduğu görülmektedir. Elde edilen alt boyut ve toplam puan ortalamalarının, ölçek alt boyut ve toplam puan orta puanlarının üstünde olması nedeniyle, öğretmen adaylarının genel olarak yaşam boyu öğrenme eğilimi içerisinde, öğrenmeye açık, yeni bilgi ve beceriler edinmeye meraklı, istekli amaçlarına ulaşmada karşılarına çıkan engellere rağmen kararlık gösteren, öğrenmelerini düzenleme konusunda çaba harcama eğilimi içinde bireyler olduğu söylenebilir.

Tablo 5 incelediğinde öğretmen adaylarının yaşam boyu eğilimlerine ilişkin kadınlara ait puan ortalamaları erkeklerden yüksek görülmektedir. Ancak alt boyutlar ve toplam puan ortalamaları arasında cinsiyete göre anlamlı fark bulunmamıştır. Öğretmen adaylarının yaşam boyu öğrenme eğilimleri cinsiyete göre değişmemektedir. Diğer bir anlatımla kadın ve erkek öğretmen adayları yaşam boyu öğrenme eğilimlerine dair benzer algılara sahiptirler. 
Tablo5.

Öğretmen Adaylarının Yaşam Boyu Öğrenme Eğiliminin Cinsiyete Göre Dağılımı

\begin{tabular}{|c|c|c|c|c|c|c|c|}
\hline Boyut & Cinsiyet & $\mathbf{N}$ & $\bar{x}$ & $\mathbf{S}$ & sd & $\mathbf{t}$ & $\mathbf{P}$ \\
\hline \multirow[t]{2}{*}{ Motivasyon } & Kadın & 202 & 29.25 & 4.97 & 238 & .77 & .71 \\
\hline & Erkek & 40 & 28.60 & 4.72 & & & \\
\hline \multirow[t]{2}{*}{ Sebat } & Kadın & 202 & 25.42 & 6.10 & 238 & .85 & .22 \\
\hline & Erkek & 40 & 24.54 & 5.26 & & & \\
\hline \multirow[t]{2}{*}{ Öğrenmeyi Düzenleme Yoksunluğu } & Kadın & 202 & 29.66 & 5.72 & 238 & 1.34 & .81 \\
\hline & Erkek & 40 & 28.35 & 5.32 & & & \\
\hline \multirow[t]{2}{*}{ Merak Yoksunluğu } & Kadın & 202 & 40.06 & 9.59 & 238 & 1.12 & .36 \\
\hline & Erkek & 40 & 38.24 & 8.23 & & & \\
\hline \multirow[t]{2}{*}{ YB Toplam } & Kadın & 202 & 124.42 & 20.91 & 238 & 1.32 & .42 \\
\hline & Erkek & 40 & 119.74 & 18.05 & & & \\
\hline
\end{tabular}

Tablo 6.

Öğretmen Adaylarının Yaşam Boyu Öğrenme Eğilimlerinin Sınıflara Göre Dağııımı

\begin{tabular}{|c|c|c|c|c|c|c|c|c|c|c|c|}
\hline Boyut & Sinıf & $\mathbf{N}$ & $\bar{x}$ & $\mathbf{S}$ & Varyans Kaynağı & KT & KO & sd & $\mathbf{F}$ & $\mathbf{p}$ & Farklı Gruplar \\
\hline \multirow[t]{5}{*}{ Motivasyon } & 1. & 70 & 29.47 & 5.16 & Gruplar Arası & 42.25 & 14.08 & 3 & .57 & .63 & - \\
\hline & 2. & 67 & 28.52 & 4.68 & Gruplar içi & 5813.37 & 24.42 & 238 & & & \\
\hline & 3. & 62 & 29.52 & 4.33 & Toplam & 5855.63 & & 241 & & & \\
\hline & 4. & 43 & 29.04 & 5.72 & & & & & & & \\
\hline & Toplam & 242 & 29.14 & 4.92 & & & & & & & \\
\hline \multirow[t]{5}{*}{ Sebat } & 1. & 70 & 25.60 & 5.97 & Gruplar Arası & 126.62 & 42.20 & 3 & 1.18 & .31 & - \\
\hline & 2. & 67 & 24.12 & 5.70 & Gruplar içi & 8464.78 & 35.56 & 238 & & & \\
\hline & 3. & 62 & 25.91 & 5.94 & Toplam & 8591.40 & & 241 & & & \\
\hline & 4. & 43 & 25.65 & 6.35 & & & & & & & \\
\hline & Toplam & 242 & 25.28 & 5.97 & & & & & & & \\
\hline Öğrenmeyi & 1. & 70 & 31.22 & 4.60 & Gruplar Arası & 355.02 & 118.34 & 3 & 3.80 & $.01^{*}$ & Freshmen and \\
\hline Düzenleme & 2. & 67 & 28.15 & 6.23 & Gruplar içi & 7407.00 & 31.12 & 238 & & & Sophomores \\
\hline \multirow[t]{3}{*}{ Yoksunluğu } & 3. & 62 & 29.33 & 5.66 & Toplam & 7762.02 & & 241 & & & \\
\hline & 4. & 43 & 28.74 & 5.80 & & & & & & & \\
\hline & Toplam & 242 & 29.45 & 5.67 & & & & & & & \\
\hline Merak & 1. & 70 & 42.11 & 6.93 & Gruplar Arası & 1242.04 & 414.01 & 3 & 4.92 & $.00^{*}$ & Freshmen and \\
\hline \multirow[t]{4}{*}{ Yoksunluğu } & 2. & 67 & 36.35 & 10.17 & Gruplar içi & 20006.58 & 84.06 & 238 & & & Sophomores \\
\hline & 3. & 62 & 39.89 & 10.37 & Toplam & 21248.62 & & 241 & & & \\
\hline & 4. & 43 & 41.09 & 8.84 & & & & & & & \\
\hline & Toplam & 242 & 39.76 & 9.38 & & & & & & & \\
\hline \multirow[t]{5}{*}{ Total } & 1. & 70 & 128.40 & 18.36 & Gruplar Arası & 4499.05 & & 3 & 3.68 & $.01^{*}$ & \\
\hline & 2. & 67 & 117.16 & 21.25 & Gruplar içi & 96831.37 & 1499.68 & 238 & & & Freshmen and \\
\hline & 3. & 62 & 124.66 & 20.44 & Toplam & 101330.42 & 406.85 & 241 & & & Sophomores \\
\hline & 4. & 43 & 124.53 & 20.84 & & & & & & & \\
\hline & Toplam & 242 & 123.64 & 20.50 & & & & & & & \\
\hline
\end{tabular}

Tablo 6 incelendiğinde öğretmen adaylarının yaşam boyu öğrenme eğilimlerine ilişkin “öz düzenleme yoksunluğu", "merak yoksunluğu" ve "toplam" puanları arasında istatistiksel olarak sınıf düzeyleri bakımından anlamlı farkların olduğu görülmektedir. Farklıı̆̆ın hangi gruplar arasında olduğunu bulmak için yapılan Scheffe testi sonuçlarına göre farkların 1.ve 2. sınıf puan ortalamasından kaynaklandığı diğer sınıf puan ortalamaları arasında ise istatistiksel olarak anlamlı bir farkın olmadığı belirlenmiştir. Ayrıca ortalamaların tamamında en yüksek puan ortalamalarının 1. sınıf, en düşük ortalamaların ise 2.sınıf öğretmen adaylarında olduğu görülmektedir. Bulgulara dayalı olarak öğretmen adaylarının yaşam boyu öğrenme eğilimlerinin 1.sınıftan 2.sınıfa geçtiklerinde düşüş gösterdiği daha sonra tekrar arttığı söylenebilir.

Öz yeterlik ve yaşam boyu öğrenme eğilimi arasında ilişkinin olup olmadığının belirlenmesi amacı ile yapılan Pearson korelasyon katsayısı sonuçları Tablo 7'de verilmiştir. 
Tablo 7.

Öz yeterlik ve Yaşam Boyu Öğrenme Eğilimlerinin Ilişkisi

\begin{tabular}{lrrrrr} 
& & & & \\
ÖY & Motivasyon & Sebat & $\begin{array}{r}\text { Ögrenmeyi Düzenleme } \\
\text { Yoksunluğu }\end{array}$ & $\begin{array}{r}\text { Merak } \\
\text { Yoksunluğu }\end{array}$ & $\begin{array}{r}\text { Yaşam Boyu } \\
\text { Toplam }\end{array}$ \\
\hline Başlama & $.41^{* *}$ & $.43^{* *}$ & $.36^{* *}$ & $.38^{* *}$ & $.50^{* *}$ \\
Yılmama & $.44^{* *}$ & $.46^{* *}$ & $.27^{* *}$ & $.29^{* *}$ & $.45^{* *}$ \\
Sürdürme & $.24^{* *}$ & $.29^{* *}$ & .09 & $.17^{* *}$ & $.25^{* *}$ \\
ÖY Toplam & $.47^{* *}$ & $.50^{* *}$ & $.35^{* *}$ & $.38^{* *}$ & $.53^{* *}$ \\
\hline
\end{tabular}

Tablo 7'de görüldüğü gibi öğretmen adaylarının öz yeterlik ve yaşam boyu öğrenme eğilimleri arasında orta (.53) düzeyde, pozitif yönlü anlamlı bir ilişki vardır. Sunulan değişkenler arasında en güçlü pozitif ilişkinin öz yeterlik boyutlarından "yılmama" ve yaşam boyu öğrenme eğilimlerinden "sebat" arasında gözlendiği anlaşılmaktadır. Bununla birlikte öz yeterlik boyutlarından sürdürmenin, yaşam boyu öğrenme eğilimlerinden olan öz düzenleme yoksunluğuyla ilişkisinin olmadığı görülmektedir.

Tablo 8.

Öz yeterlik Inancının Yaşam Boyu Öğrenme Eğilimini Yordanmasına ilișkin Regresyon Sonuçları

\begin{tabular}{lrrrrr}
\hline Değişken & $\mathbf{B}$ & Standart Hata & $\boldsymbol{\beta 2}$ & $\mathbf{t}$ & $\mathbf{P}$ \\
\hline Öz Yeterlik & 50.64 & 7.54 & .53 & 6.71 & .00 \\
$\mathrm{R}=.54$ & $\mathrm{R}^{2}=.28$ & & & & \\
$\mathrm{~F}=95.84$ & $\mathrm{p}=.00$ & & & & \\
\hline
\end{tabular}

Tablo 8 incelendiğinde öz yeterlik inancının, yaşam boyu öğrenme eğiliminin anlamlı bir yordayııısı olduğu görülmektedir $\left(R=.54, R^{2}=.28, F=95.84 ; p<.01\right)$. Yaşam boyu öğrenme eğilimine ilişkin toplam varyansın, $\% 28.00$ 'sinin öz yeterlik inancı ile açıklandığı ifade edilebilir.

\section{Tartışma, Sonuç ve Öneriler}

Araştırma ile sınıf öğretmeni adaylarının öz yeterlik düzeyleri ve yaşam boyu öğrenme eğilimlerini belirlemek, adayların öz yeterlik düzeyi ile yaşam boyu öğrenme eğilimi arasında ilişki olup olmadığını tespit etmek, ilişki varsa nasıl bir ilişki olduğunu ortaya çıkarmak amaçlanmıştır.

Araştırma bulgularına göre öğretmen adaylarının öz yeterlik toplam puan ortalaması 62.70'dir. Adayların öz yeterlik ölçeğinden aldıkları puanların ortalaması ölçek orta puanının(51) üstündedir. Adayların öz yeterliklerine ilişkin "başlama", "yılmama" "sürdürme" alt boyutları ortalama puanları alınabilecek ölçek orta puanından az da olsa yüksektir. Buna göre sınıf öğretmeni adaylarının akademik öz yeterlik inançlarının genel olarak yüksek olduğu düşünülebilir. Bu bulgu yapılmış bazı araştırmaların bulguları (Oğuz, 2009; Yılmaz, Gürçay \& Ekici, 2007) ile de örtüşmektedir.

Erkek öğretmen adaylarııı öz yeterlik düzeyleri kadın adaylara göre az da olsa yüksek bulunmuştur. Ancak yapılan "t testi" farkın anlamlı olmadığını, öğretmen adaylarının öz yeterlik düzeyinin cinsiyete göre değişmediğini, cinsiyet farklıı̆ııın öz yeterlik düzeyi üzerinde bir etkisinin olmadığııı göstermektedir. Öz yeterlik algııının cinsiyete göre değişmediği bulgusu birçok araştırma (Altunçekiç, Yaman \& Koray, 2005; Azar, 2010; Çetin, 2007; Ekici, 2008; Saraçoğlu,2018; Saracaloğlu, Karasakaloğlu \& Evin-Gencel, 2010; Şensoy \& Aydoğdu, 2008; Taşkın \& Hacı̈meroğlu, 2010; Uysal, 2013; Yenice, 2012; Yıldırım \& Illhan, 2010) bulgusuyla tutarlııı göstermektedir. Ancak öz yeterlik algısının cinsiyete göre farklılık gösterdiği bulgusuna erişen araştırmalar da (Aypay, 2010; Britner \& Pajares, 2006; Ekici, 2005) mevcuttur. Örneğin Bong (1999) ile Durdukoca (2010) çalışmalarında erkek öğretmen adayların öz yeterlik algılarının kadın adaylardan; Shahid ve Thompson (2001); ile Yenilmez ve Kakmacı (2008) ise kadın öğretmen adayların erkek adaylardan daha fazla öz yeterlik algısına sahip olduğu şeklinde bulgulara ulaşmıştır. Sonuç olarak öz-yeterliğin cinsiyete göre değiştiğini bulgulayan araştırmalarda da bu farkın kadın ya da erkek lehine farklılaşığı bulguları elde edilmektedir. Çalışmalar değerlendirildiğinde öz yeterliğin cinsiyete göre farklııı̆ına ilişkin tutarlılık sağlanamadığını söylemek doğru olacaktır. Bu durum çalışılan örneklem grupları, kullanılan ölçekler ve çalışmaların gerçekleştiği zaman farklııılarından kaynaklanmış olabilir. Araştırmada da cinsiyet değişkeni açısından fark çıkmaması kadın ve erkek adayların aldıkları eğitimlerden benzer oranda yararlandıkları ve kendilerini geliştirdikleri düşünülebilir. 
Öğretmen adayları öz yeterliğinin sınıf düzeyine göre değişmediği bulgulanmıştır. Araştırma ile elde edilen bulguyu destekleyen çalışmalar (Berkant \& Ekici 2007; Cerit, 2010; Uysal, 2013; Yenice, 2012) mevcuttur. Bununla beraber (Altunçekiç et. al., 2005; Durdukoca, 2010; Kozcu et. al., 2007; Yenilmez \& Kakmacı, 2008) tarafından yapılan araştırmalarda öğrenim görülen sınıf düzeyine göre öğretmen adaylarının öz yeterlik düzeyleri arasında farkıııklar elde edilmiştir. Araştırmadan elde edilen bu sonuç geçirilen öğrenim yaşantılarının öğretmen adaylarının öz yeterlik inançlarına katkı sağlamadığı, bu inançları daha güçlü hale getirmediği şeklinde yorumlanabilir.

Öğretmen adaylarının yaşam boyu öğrenme eğilimi ölçeğinden elde ettikleri toplam puan ve alt boyut puanlarının ölçek orta puanlarından yüksek olduğu ortaya çıkmıştır. Yapılan benzer çalışmalarda bu konuda farklı bulgular mevcuttur. Çalışmanın bulgularına benzer şekilde öğretmen adaylarının yaşam boyu öğrenme eğilimlerini yüksek bulan (Ayra, 2015; Demirel \& Akkoyunlu 2010; Ergün \& Cömert Özata, 2016; Gür Erdoğan, 2014) araştırmaların yanı sıra öğretmen adaylarının yaşam boyu öğrenme eğilimlerinin düşük olduğu bulgusuna ulaşan çalışmalar (Diker-Coşkun \& Demirel, 2012; Karakuş, 2013; Kılıç, 2014; Savuran, 2014; Şahin et. al., 2010; Tunca, Alkın Şahin \& Aydın, 2015) mevcuttur. Öğretmen adaylarının yaşam boyu öğrenme faaliyetlerine katılma, düzenleme, sürdürme, kararlığında ve merakı oldukları söylenebilir Diğer bir ifade ile öğretmen adayları sürekli öğrenme ve kendini geliştirme konusunda istekli bulunmuşlardır. Kara ve Kürüm (2007) sınıf öğretmeni adaylarının yaşam boyu öğrenmeyi, önemli ve gerekli gördüklerini belirlemiştir. Ancak elde edilen seviyenin artırılması gereklidir.

Öğretmen adaylarının yaşam boyu öğrenme eğilimleri cinsiyet farkına göre incelendiğinde kadın adaylara ait puan ortalamaları erkek adaylardan daha yüksek görülmektedir. Ancak alt boyutlar ve toplam puan ortalamaları arasında cinsiyete göre anlamlı bir farklılık göstermediği belirlenmiştir. Öğretmen adaylarının yaşam boyu öğrenme eğilimlerinin cinsiyete göre değişmediği sonucuna ulaşılmışır. Diğer bir anlatımla kadın ve erkek öğretmen adaylarının yaşam boyu öğrenme eğilimleri benzerlik göstermektedir. Araştırmadan elde edilen bu sonuçları destekler nitelikte araştırmalar (Dündar, 2016; Oral \&Yazar, 2015; Savuran, 2014; Şahin, Akbaşlı \& Yanpar-Yelken 2010) mevcuttur. Ancak cinsiyete göre anlamlı farklılık olduğunu ortaya koyan çalışmalar da vardır. Bu çalışmaların bir kısmında kadın öğretmen adaylarının (Demirel \& Akkoyunlu, 2010; Diker-Coşkun, 2009; Evin-Gencel, 2013; İzci \& Koç, 2012; Karakuş, 2013) bir kısmında ise erkek öğretmen adaylarının (DikerCoşkun \& Demirel, 2012; Ekşioğlu, Tarhan \& Gündüz-Çetin, 2017) daha yüksek düzeyde yaşam boyu öğrenme eğilimlerine sahip olduklarına dair sonuçlara ulaşılmışır. Araştırmalarında kadın adayların yaşam boyu öğrenme eğilimini yüksek bulan Diker-Coşkun ve Demirel (2012) bunun sebebini kadınların toplumsal cinsiyet rollerine karşın, statü kazanma, iş yaşamında olumlu ilerleyebilme arzusu ve çabasından kaynaklanabileceği şeklinde yorumlamıştır. Bununla beraber Ekşioğlu, Tarhan ve Gündüz-Çetin (2017) de erkek adayların kadınlara göre yüksek puan almasında kültürel olarak erkeklere tanınan eğitim fırsatları çeşitliliğinin etkisi olabileceğini belirtmişlerdir. Farklı sonuçlar elde edilmesinde ölçme araçları ve ulaşılan katılımcı gruplarındaki çeşitliliğin etkisi olduğu düşünülebilir. Araştırmada cinsiyete göre yaşam boyu öğrenme eğiliminde anlamlı bir farkılıık olmasının sebebi tüm adayların yaşam boyu öğrenmeyi öğretmenlik mesleğinin gereği olarak algılamalarının etkisi olabilir.

Genel olarak öğretmen adaylarının sınıflara göre yaşam boyu öğrenme eğilimlerinin yüksek düzeyde olduğu söylenebilir. Öğretmen adaylarının yaşam boyu öğrenme eğilimleri sınıflara göre "motivasyon" ve "sebat" alt boyutlarında anlamlı bir fark göstermemektedir. Ancak "öz düzenleme yoksunluğu", "merak yoksunluğu" ve "toplam" puanları arasında istatistiksel olarak anlamlı farkların olduğu görülmektedir. Farklılı̆ın 1.ve 2. sınıf puan ortalamasından kaynaklandığı diğer sınıf puan ortalamaları arasında ise istatistiksel olarak anlamlı bir farkın olmadığı belirlenmiştir. Buna göre 1. sınıfta öğrenim gören öğretmen adaylarının yaşam boyu öğrenme eğilimlerinin daha yüksek olduğu ifade edilebilir. Bulgulara dayalı olarak öğretmen adaylarının yaşam boyu öğrenme eğilimlerinin 1.sınıftan 2.sınıfa geçtiklerinde düşüş gösterdiği daha sonra tekrar arttı̆̆ı ama artışın 1 sınıftaki adayların ortalamalarını geçmediği söylenebilir. Oral ve Yazar (2015) araştırmalarında benzer sonuçları 3. sınıftaki öğretmen adayları, Ekşioğlu, Tarhan ve Gündüz-Çetin (2017) 2. sınıfta öğrenim gören öğretmen adayları, Demirel ve Akkoyunlu (2010) ise, son sınıf öğretmen adayları lehine anlamlı fark elde edilmişlerdir. Diker Coşkun (2009)'un yaptığı araştırmada üniversite öğrencilerinin sınıf düzeyine göre yasam boyu öğrenme eğilimleri puan ortalamaları arasında anlamlı fark bulunmamışıı. Sınıf düzeyi arttıkça yükseköğretimde alınan eğitimle yaşam boyu öğrenme eğiliminin artması beklenmektedir. Ulaşılan sonuçlar öğretmen adaylarının yaşam boyu öğrenme eğilim özelliklerinde üniversitede aldıkları eğitimden ziyade kendi kişisel özelliklerinin etkisi olduğu şeklinde yorumlanabilir. Zira adayların yaşam boyu öğrenme eğilimleri dört yıl boyunca alınan akademik eğitim ile olumlu bir değişim göstermediği gibi birinci sınıf öğretmen adaylarının yaşam boyu 
öğrenme eğilimleri diğer sınıflardan yüksek bulunmuştur. Öğrencilerin yaşam boyu öğrenme becerilerini üniversite eğitiminde geliştirebilmesi, akademik yönlendirme, sosyal-kültürel çevre ve kurumsal olanakların yeterliği ile ilişkilidir (Darwin \& Palmer, 2008; Wenger, 2002). Wenger (2002) üniversiteye gelen öğrencilerin etkin danışmanlar tarafından yönlendirilmesinin bir çeşit sosyal öğrenme sistemi oluşturabileceği, danışmanlık sürecinin öğrencinin entelektüel ve mesleki gelişimini etkileyen, üniversite eğitiminde öğretimi tamamlayan unsur olarak görülmesi gerektiğini vurgulamaktadır. Darwin ve Palmer (2008) de üniversite danışmanlarının öğrenciye akademik anlamda rehberlik etmenin yanı sıra öğrenmeyi öğrenme becerisi kazandırma, yaşam boyu öğrenme farkındalığı oluşturma görevlerini de yürütmesini önermektedir.

Araştırmadan elde edilen diğer bir sonuç öğretmen adaylarının öz yeterlik düzeyleri ile yaşam boyu öğrenme eğilimleri arasında anlamlı bir ilişkinin olduğudur. İki değişken arasında düşük düzeyde pozitif yönlü bir ilişki olduğu tespit edilmiştir. Öğretmen adaylarının öz yeterlik düzeylerinin artması durumunda yaşam boyu öğrenme eğilimlerinin de artacağı öngörülebilir. Analiz sonuçları incelendiğinde öz yeterlik inancının, yaşam boyu öğrenme eğiliminin anlamlı bir yordayıcısı olduğu görülmektedir. Yaşam boyu öğrenme eğilimine ilişkin toplam varyansın, \%28'si öz yeterlik inancı ile açıklanmaktadır. Öz yeterlik inançlarının öğretmen davranışları ve birçok olumlu öğretim uygulamaları için anlamlı iyi bir yordayıcı olduğu belirtilmektedir (Gibson \& Dembo, 1984; Goddard et.al., 2004). Yüksek yeterlik duygusu olan öğretmenler, yüksek akademik standartlara sahiptirler ki bunların başında yaşam boyu öğrenme eğilimi yer alır. Zira öz yeterliği yüksek öğretmenler mesleklerine daha çok yönelen, bilişsel gelişimine çaba harcayan (Schmitz, 2000) motivasyonu yüksek, sabırlı, öz düzenlemeye sahip, yeniliklere karşı meraklı öğrenmeye açık ve öğretim konusunda daha arzulu ve tutkulu davranmaktadırlar (Bıkmaz, 2004) ki bu özellikler yaşam boyu öğrenmeye açık bireylerin özellikleridir. Bu anlamda öğretmenlerin öz yeterlik algılarını ve yaşam boyu öğrenme eğilimlerini artırmanın temeli meslek öncesi aldıkları eğitim-öğretimin kalitesini artırmakla ilgilidir.

Toplumsal refah ve yaşam kalitesinin artmasında yükseköğretim kurumları önemli katkılar sağlar. Bu yüzden yaşam boyu öğrenmenin gerçekleşebilmesi için yükseköğretim programlarının öğrencilerin kendi öğrenmelerini kontrol edebilecekleri ve araştırma sorumluluğunu alabilecekleri etkinliklerle düzenlenmesi gerekmektedir (Appley, 2001; Coşkun \& Demirel, 2012). Parkinson'a (1999) göre yaşam boyu öğrenme yetkinliğinde bireylerin yetiştirilebilmesi için, yükseköğretim programlarında, öğrencilerin kendi öğrenme sorumluluklarını üstlendiği sınıf dışı etkinliklere ve aktif öğrenme metotlarına yer vermek, öğrencilere nasıl öğreneceklerini öğretmek, kendi eğitim süreçlerini yönetebilmelerini ve problemlerin içinde görev almalarını sağlamak, öz değerlendirme yapmaları için cesaretlendirmek gerekmektedir. Sonuç olarak Türkiye'de yükseköğretim kurumlarında özellikle de eğitim fakültelerinde öğrenme ortamları düzenlenirken bireylerin öz yeterlik ve yaşam boyu öğrenme eğilimini arttıran akademik ve sosyo-kültürel programlar hazırlanmalı, buna uygun öğrenme ortamları oluşturulmalıdır. Öğretmenlerin "yaşam boyu öğrenen" birey yetiştirmedeki önemli rolleri olduğu unutulmamalıdır. Öğretmen adaylarının eğitimleri, hem yaşam boyu öğrenen bireyler olarak yetiştirilmesi, hem de yaşam boyu öğrenen bireyler yetiştirmek için sahip olmaları gereken bilgi becerileri içeren kişisel ve sosyal gelişimlerine, öz yeterliklerine katkı sağlayacak öğrenen merkezli hazırlanmış programlarla gerçekleştirilmelidir. 
Serap Tüfekçi Aslım, Handan Kocabatmaz - Uluslararası Eğitim Programları ve Öğretim Çalışmaları Dergisi, 9(1), 2019, 179-202

\section{References}

Akkoyunlu, B., Orhan, F. \& Umay, A. (2005). Bilgisayar öğretmenleri için "bilgisayar öğretmenliği öz yeterlik ölçeği" geliştirme çalışması. Hacettepe Üniversitesi Eğitim Fakültesi Dergisi, 29, 1-8.

Altunçekiç, A., Yaman, S. \& Koray, Ö. (2005). Öğretmen adaylarıın öğretmen öz-yeterlik inanç düzeyleri ve problem çözme becerileri üzerine bir araştırma (Kastamonu ili örneği). Kastamonu Eğitim Dergisi, 13(1), 93102.

Appley, D. (2001). The covert curriculum, the lifelong learning skills you can learn in college. Retrieved from: http://www.hammiverse.com/apbio/student_success_resources/lifelong_learning_skills.

Aspın, N. D. \& Chapman, J. D. (2000). Lifelong learning, concepts and conception. International Journal of Lifelong Education, 19(1), 2-19.

Ay, B. (2007). Öğretmenlerin öz-yeterlikleri ve örgütsel vatandaşlık davranışı. Unpublished Master's Thesis, Afyon Kocatepe University, Afyonkarahisar.

Aypay, A. (2010). Genel öz yeterlik ölçeğinin (GÖYÖ) Türkçe'ye uyarlama çalışması. Inönü Üniversitesi Eğitim Fakültesi Dergisi, 11(2),113-131.

Ayra, M. (2015). Öğretmenlerin yaşam boyu öğrenme eğilimlerinin mesleki öz yeterlik inançları ile ilişkisi. Unpublished Master's Thesis, Amasya University, Amasya.

Azar, A. (2010). Ortaöğretim fen bilimleri ve matematik öğretmeni adaylarının öz yeterlilik inançları. ZKÜ Sosyal Bilimler Dergisi, 6(12), 235-252.

Bandura, A. (1994). Self-Efficacy. In V. S. Ramachandran (Ed.), Encyclopedia of human behavior (vol. 4, pp. 71 81). San Diego: Academic Press.

Bandura, A. (1997). Self-efficacy, the exercise of control. New York: W. H. Freeman and Company.

Berkant, H. G. \& Ekici, G. (2007). Sınıf öğretmeni adaylarının fen öğretiminde öğretmen öz-yeterlik inanç düzeyleri ile zekâ türleri arasındaki ilişkinin değerlendirilmesi. Çukurova Üniversitesi Sosyal Bilimler Enstitüsü Dergisi, 16(1), 113-132.

Bıkmaz, F. H. (2002). Ortaöğretim fen bilimleri ve matematik öğretmeni adaylarının öz yeterlilik inançları. Eğitim Bilimleri ve Uygulama, 1(2), 197-210.

Bıkmaz, F. H. (2004). Öz yeterlik inançları. In: Y. Kuzgun ve D. Deryakulu (Eds.). Eğitimde bireysel farklılıklar (pp. 289-314). Ankara: Nobel Yayın Dağıtım.

Bong, M. (1999). Personal factors affecting the generality of academic self-efficacy judgments, gender, ethnicity and relative expertise. The Journal of Experimental Education, 67(4), 315-331.

Britner, S. L. \& Pajares, F. (2006). Sources of science self-efficacy beliefs of middle school students. Journal of Research in Science Teaching, 43(5), 485-499.

Büyüköztürk, S. (2007). Sosyal bilimler için veri analizi el kitabı (8 ${ }^{\text {th }}$ edition). Ankara: Pegem Yayıncılık.

Carver, C. S. \& Scheier, M. (2003). Optimisim. In S.J. Lopez and C.R. Snyder (Eds), Positive psychological assessment: A handbook of model and measures (pp. 75-89). Washington DC: American Psychological Association.

Cerit, Y. (2010). Öğretmen öz-yeterlik ölçeğinin geçerlik ve güvenirlik çalışması ve sınıf öğretmeni adaylarını öz -yeterlik Inançları. Eğitimde Kuram ve Uygulama, 6(1), 68-85

Çetin, B. (2007). Sınıf öğretmenliği anabilim dalı 3. sınıf öğrencilerinin matematik ve fen bilgisi öğretimi öz yeterliklerinin incelenmesi. VI. Ulusal Sınıf Öğretmenliği Eğitimi Sempozyumu. Anadolu Üniversitesi Eğitim Fakültesi, Eskişehir.

Darwin, A., \& Palmer, E. (2008). Mentoring circles in higher education. Higher Education Research \& Development, 28(2), 125-136.

Demirel, M. \& Akkoyunlu, B. (2010). Öğretmen adaylarının yaşam boyu öğrenme eğilimleri ve bilgi okuryazarlığı öz yeterlik algıları. $10^{\text {th }}$ International Educational Technology Conference (pp. 1126-1133). Boğaziçi Üniversitesi, İstanbul.

Demirel, M. (2008). Yaşam boyu öğrenmenin anahtarı, Öğrenmeyi öğrenme. 2. Ulusal Eğitim Psikolojisi Sempozyumu Bildiri Kitabı (pp. 133-145). Kültür Üniversitesi, İstanbul. 
Serap Tüfekçi Aslım, Handan Kocabatmaz - Uluslararası Eğitim Programları ve Öğretim Çalışmaları Dergisi, 9(1), 2019, 179-202

Diker-Coşkun, Y. \& Demirel, M. (2012). Üniversite öğrencilerinin yaşam boyu öğrenme eğilimleri. Hacettepe Üniversitesi Eğitim Fakültesi Dergisi, 48, 108-120.

Diker-Coşkun, Y. (2009). Üniversite öğrencilerinin yaşam boyu öğrenme becerilerinin bazı değişkenler açısından incelenmesi. Unpublished PhD Thesis, Hacettepe University, Ankara.

DPT. (2001). Sekizinci Beş Yılık Kalkınma Planı, Hayat boyu Eğitim veya Örgün Olmayan Eğitim Özel ihtisas Komisyonu Raporu. Retrieved from: www.dpt.gov.tr/DocObjects/Download/3206/oik584.pdf

Durdukoca, Ş. F. (2010). Sınıf öğretmeni adaylarının akademik öz yeterlik algılarının çeşitli değişkenler açısından incelenmesi. Abant İzet Baysal Üniversitesi Dergisi, 10(1), 69-77.

Dündar, H. (2016). Sınıf öğretmeni adaylarının yaşam boyu öğrenme eğilimlerinin incelenmesi. Unpublished Master's Thesis, Atatürk University, Erzurum.

Ekici, G. (2005). Eğitim Fakültesi öğrencilerinin öğretmenlik öz-yeterlik inançlarını etkileyen faktörler. XIV. Ulusal Eğitim Bilimleri Kongresi. Pamukkale Üniversitesi Eğitim Fakültesi, Denizli.

Ekici, G. (2008). Sınıf yönetimi dersinin öğretmen adaylarının öğretmen öz-yeterlik algı düzeyine etkisi. Hacettepe Eğitim Fakültesi Dergisi, 35, 98-110.

Ekşioğlu, S., Tarhan S. \& Çetin Gündüz, H. (2017) Yaşam boyu öğrenme eğilimleri İle özyetkinlik beklentisi ve kişilik özellikleri arasındaki ilişkinin incelenmesi, Kastamonu Eğitim Dergisi, 25(5) 1925-1940.

Ergün, S. \& Cömert-Özata, S. (2016). Okul öncesi öğretmenliği bölümüne devam eden öğrencilerin yaşam boyu öğrenme eğilimleri. International Journal of Human Sciences, 13(1), 1851-1861.

Ersoy, A. \& Yılmaz, B. (2009). Yaşam boyu öğrenme ve Türkiye'de halk kütüphaneleri. Türk Kütüphaneciliği, 23(4), 803-834.

Gibson, S. \& Dembo, M. H. (1984). Teacher efficacy, a construct validation. Journal of Educational Psychology, 76(4), 569-582.

Goddard, R. D. (2001). Collective efficacy, A neglected construct in the study of the schools and student achievement. Journal of Educational Psychology, 93(3), 467-476.

Goddard, R. D., Hoy, W.K. \& Woolfolk-Hoy, A. (2000).Collective teacher efficacy, its meaning, measure, and impact on student achievement. American Education Research Journal, 37(2),479-507.

Golightly, T. R. (2007). Defining the components of academic self-efficacy in Navajo American Indian high school students. Unpublished PhD Thesis, Brigham Young University.

Gravetter, J. F. \& Forzano, L. B. (2012). Research methods for the behavioral sciences (4 ${ }^{\text {th }}$ edition). USA: Linda Schreiber-Ganster.

Gür-Erdoğan, D. (2014). Öğretmen adaylarının yaşam boyu öğrenme eğilimlerine etki eden faktörler. Unpublished Master's Thesis, Abant İzzet Baysal University, Bolu.

HBÖ (2009). 2009-2013 Hayat Boyu Öğrenme Strateji Belgesi.

İzci, E. \& Koç, S. (2012). Öğretmen adaylarının yaşam boyu öğrenmeye ilişkin görüşlerinin belirlenmesi. Adıyaman Üniversitesi Sosyal Bilimler Enstitüsü Dergisi, 5(9), 101-114.

Kara, A. \& Kürüm, D. (2007) Sınıf öğretmeni adaylarının "Yaşam boyu öğrenme" kavramına yükledikleri anlam (Anadolu Üniversitesi Eğitim Fakültesi Örneği) 16. Ulusal Eğitim Bilimleri Kongresi, Gaziosmanpaşa Üniversitesi Eğitim Fakültesi, Tokat.

Karakuş, C. (2013). Meslek yüksekokulu öğrencilerinin yaşam boyu öğrenme yeterlikleri. Eğitim ve Öğretim Araştırmaları Dergisi, 2(3), 26-35.

Karasar, N. (2013). Bilimsel araştırma yöntemi. Ankara: Nobel Yayınevi.

Kılıç, Ç. (2014). Öğretmen adaylarının yaşam boyu öğrenmeye yönelik algıları. Eğitim ve Öğretim Araştırmaları Dergisi, 3(4), 79-87.

Knapper, C. \& Cropley, A. J. (2000). Lifelong learning in higher education. London: KoganPage.

Kozcu-Çakır, N. ; Şenler, B. \& Taşkın-Göçmen, B. (2007). Fen bilgisi ve sınıf öğretmenliği anabilim dalında öğrenim gören öğretmen adaylarının öz-yeterlik inançlarının belirlenmesi (Muğla Üniversitesi Örneği). 16. Ulusal Eğitim Bilimleri Kongresi. Gaziosmanpaşa Üniversitesi, Eğitim Fakültesi, Tokat. 
Serap Tüfekçi Aslım, Handan Kocabatmaz - Uluslararası Eğitim Programları ve Öğretim Çalışmaları Dergisi, 9(1), 2019, 179-202

Leithwood, K. (2007). What we know about the educational leadership. In: J.M. Burger, C. Webber ve P. Knick. (Eds.) Intelligent Leadership, Springer (pp. 41-66).

Oğuz, A. (2012). Sınıf Öğretmeni Adaylarının Akademik Öz Yeterlik İnançları. Anadolu Journal Of Educational Sciences International, 2(2), 15-28.

Oral, B. \& Yazar, T. (2015). Öğretmen adaylarının yaşam boyu öğrenmeye ilişkin algılarının çeşitli değişkenlere göre incelenmesi. Elektronik Sosyal Bilimler Dergisi, 14(52), 1-11.

Özenoğlu-Kiremit, H. (2006). Fen bilgisi öğretmenliği öğrencilerinin biyoloji ile ilgili öz yeterlik inançlarının karşılaştırılması. Yayımlanmamış yüksek lisans tezi. Dokuz Eylül Üniversitesi, Eğitim Bilimleri Enstitüsü, İzmir.

Pajares, F. (2002). Overview of social cognitive theory and of self-efficacy. Retrieved from: http://www.emory.edu/EDUCATION/mfp/eff.html.

Parkinson, A. (1999). Developing the attribute of lifelong learning. 29th ASEE/IEEE Frontiers in Education Conference, November10 - 13, San Juan, PuertoRico.

Saracaloğlu, A. S., Karasakaloğlu, N., \& Gencel-Evin, i. (2010).Türkçe öğretmenlerinin öz-yeterlik düzeylerinin çeşitli değişkenlere göre incelenmesi. Elektronik Sosyal Bilimler Dergisi, 9(33),265-283.

Saraçoğlu, G.(2018).Öğretmen adaylarının akademik öz yeterliklerinin incelenmesi. Uluslararası Eğitim Programları ve Öğretim Dergisi, 8(2), 255-274.

Savuran, Y. (2014). Ingilizce öğretmen adaylarının mentorlarına kıyasla yaşam boyu öğrenme becerileri. Yayınlanmamış yüksek lisans tezi. Hacettepe Üniversitesi, Sosyal Bilimler Enstitüsü, Ankara.

Schunk, D. H. (1996). Self-Efficacy for learning and performance. Annual Conference of the American Educational Research Association. Retrieved from: http://www.eric.ed.gov/PDFS/ ED394663.pdf.

Selvi, K. (2011). Öğretmenlerin yaşam boyu öğrenme yeterlikleri. Uluslararası Eğitim Programları ve Öğretim Dergisi, 1(1), 61-69.

Shahid, J. \& Thompson D. (2001), Teacher efficacy, a research synthesis. Annual Meeting of the American Educational Research Association, Seattle.

Sherer, M., Maddux, J.E., \& Mercandante, B. (1982) The self-efficacy scale, construction and validation. Psychol Reports, 51, 663-671.

Shuman, L. J., Besterfield-Sacre, M., \& McGourty, J. (2005). The ABET “Professional skills" - can they be taught? Can they be assessed? Journal of Engineering Education, 94(1), 41-55.

Şahin, E. (2010). İlköğretim sınıf öğretmenlerinin öğretim stili tercihlerinin, cinsiyetlerinin, mesleki kıdemlerinin, öz yeterlik algılarının ve özyönetimli öğrenmeye hazırbulunuşluk düzeylerinin mesleki yeterlikleri üzerindeki etkisi. Unpublished PhD Thesis, Yıldız Teknik University, İstanbul.

Şahin, M., Akbaşlı ,S. \& Yanpar-Yelken, T. (2010). Key competences for lifelong learning, the case of prospective teachers. Educational Research And Review , 5(10), 545-556.

Şensoy, O. \& Aydoğdu, M. (2008). Araştırma soruşturma tabanlı öğrenme yaklaşımının fen bilgisi öğretmen adaylarının fen öğretimine yönelik öz-yeterlik inanç düzeylerinin gelişimine etkisi. Gazi Üniversitesi Gazi Eğitim Fakültesi Dergisi, 28(2), 69-93.

Tschannen-Moran, M. \& Woolfolk-Hoy, A. (2001). Teacher efficacy, capturing an elusive construct. Teaching and Teacher Education, 17(7), 783-805.

Tschannen-Moran, M. \& Woolfolk-Hoy, A. (2007). The differential antecedents of self-efficacy beliefs of novice and experienced teachers. Teaching and Teacher Education, 23, 944-956.

Tunca, N., Alkın-Şahin, S. \& Aydın, Ö. (2015). Öğretmen adaylarının yaşam boyu öğrenme eğilimleri. Mersin Üniversitesi Eğitim Fakültesi Dergisi, 11(2), 432-446.

Turan, S. (2005). Öğrenen toplumlara doğru Avrupa birliği eğitim politikalarında yaşam boyu öğrenme. Ankara Avrupa Çalışmaları Dergisi, 5(1),87-98.

Uysal, i. (2013) Öğretmen adaylarının genel öz-yeterlik inançlarının incelenmesi. Eğitim ve Öğretim Araştırmaları Dergisi, 2(2), 217-226.

Wenger, E. (2002). Communities of practice learning, meaning and identity. United Kingdom: Cambridge UniversityPress. 
Woolfolk, A. E. \& Hoy, W. K. (1990). Prospective teachers' sense of efficacy and beliefs about control. Journal of Educational Psychology, 82, 81-91.

Yenice, N. (2012). Öğretmen adaylarının öz-yeterlik düzeyleri ile problem çözme becerilerinin incelenmesi. Electronic Journal of Social Sciences, 11(39), 36-58.

Yenilmez, K. \& Kakmacı Ö. (2008). İlköğretim matematik öğretmenliği bölümü öğrencilerinin öz yeterlilik inanç düzeyleri. Eskişehir Osmangazi Üniversitesi Sosyal Bilimler Dergisi 9(2), 1-21.

Yıldırım, F. \& Illhan, İ. Ö. (2010). Genel öz yeterlik ölçeği Türkçe formunun geçerlik ve güvenilirlik çalışması. Türk Psikiyatri Dergisi, 21(4), 301-308.

Yılmaz, M., Gürçay, D. \& Ekici, G. (2007) Akademik öz yeterlik ölçeğinin Türkçe'ye uyarlanması. Hacettepe Üniversitesi Eğitim Fakültesi Dergisi, 33, 53-259.

Yılmaz, M., Köseoğlu, P., Gerçek, C. \& Soran, H. (2004). Yabancı dilde hazırlanan bir öğretmen öz yeterlik ölçeğinin Türkçe'ye uyarlanması. Hacettepe Üniversitesi Eğitim Fakültesi Dergisi, 27, 260-267. 
